\title{
Condições físicas de formação de associações metamórficas do cinturão ultramáfico Carrancas-Liberdade, MG
}

\author{
Soraya Almeida ${ }^{1}$
}

\begin{abstract}
Resumo Na região sul de Minas Gerais, dezenas de corpos ultramáficos alóctones ocorrem associados a rochas sedimentares do Ciclo Deposicional Andrelândia, ao longo da zona de interferência entre as Faixas Brasília e Ribeira. Estes compõem um cinturão parcialmente inserido em terrenos do domínio tectônico da Faixa Brasília e parcialmente contidos no domínio tectônico da Faixa Ribeira. Os resultados do trabalho aqui apresentado revelam que, apesar das semelhanças existentes entre as rochas de ambos os domínios, tipos modalmente semelhantes registram diferentes histórias evolutivas. As rochas de alto grau pertencentes ao domínio da Faixa Ribeira (metapiroxenitos) revelam condições de equilíbrio sob temperaturas superiores (entre 700 e $900^{\circ} \mathrm{C}$ ) em relação aos seus congêneres associados ao domínio tectônico da Faixa Brasília (máximo de $640^{\circ} \mathrm{C}$ ). Estas condições contrastantes são acompanhadas por diferentes estilos de deformação. No domínio tectônico da Faixa Brasília, o pico metamórfico está associado ao crescimento de piroxênio e olivina, seguido por uma deformação que afeta as associações de alto grau de forma discreta. As principais estruturas nesta região estão associadas a uma fase retrometamórfica, representada pela formação de rochas hidratadas a partir das associações de alto grau. No domínio da Faixa Ribeira, o metamorfismo progressivo é concomitante a uma deformação intensa, indicando que o pico metamórfico coincide com o desenvolvimento das estruturas dominantes nos corpos ultramáficos.
\end{abstract}

Palavras-chave: rochas ultramáficas, geotermobarometria, metamorfismo.

\begin{abstract}
Physical conditions of metamorphic associations of Carrancas-Liberdade ultramafic belt, MG. Allochthonous ultramafic bodies occur associated with metasediments at Andrelândia Depositional Cycle in southern Minas Gerais. They cross regions belonging to the domains of the Brasília Belt and the interference tectonic zone between this and the Ribeira Belt. This paper discusses the differences in the metamorphic evolution of ultramafic rocks of both domains, based on equilibrium reactions, textural analysis and application of geothermometers. The high-grade rocks of a Ribeira Belt Tectonic Domain (meta-pyoxenites) show equilibrium conditions under higher temperatures $\left(700\right.$ to $\left.900^{\circ} \mathrm{C}\right)$ regarding to their congeners in the Brasília Belt Tectonic Domain (maximum of $640^{\circ} \mathrm{C}$ ). Besides these contrasting temperatures the areas show different styles of deformation. In the Brasília Belt, the metamorphic peak is associated to pyroxene and olivine growth, followed by a deformation that affects the high grade rocks only in a discreet form. The main structures in this region are associated to a retro-metamorphic phase, represented by formation of hydrated rocks over the highest grade assemblages. In the domain of the Ribeira Belt, the formation of the highest grade minerals is concomitant to an intense deformation, indicating that the metamorphic peak coincides with the development of the dominant structures of ultramafic bodies.
\end{abstract}

Keywords: ultramafic rocks, geothermobarometry, metamorphism.

INTRODUÇÃO A região sul de Minas Gerais possui dezenas de corpos ultramáficos alóctones intercalados a rochas metassedimentares proterozoicas. Estas rochas, posicionadas ao longo de falhas de empurrão e com dimensões que não ultrapassam poucos quilômetros quadrados, exibem uma grande variedade de tipos litológicos, que vão desde associações essencialmente hidratadas, como serpentinitos e clorita xistos, a associações de alto grau como metapiroxenitos. Suas texturas originais foram obliteradas por diferentes fases de metamorfismo e deformação que afetaram esta região e várias origens foram propostas para estas rochas. Magalhães (1985) identifica características de sequências komatiíticas e também de rochas do "tipo-alpino" ao longo do cinturão. Bebert (1981) propõe uma origem relacionada a sequências ofiolíticas para corpo ultramáfico Morro do Corisco, em Liberdade. Nilson (1984) sugere que algumas destas rochas representem intrusões diferenciadas em sills. Almeida $(1992,1998)$ atribui a estes corpos caráter original intrusivo, com formação de associações cumuláticas a partir de magmas toleíticos continentais. Ribeiro et al. (1995) consideram a possibilidade de estes corpos representarem fragmentos do manto litosférico e Pinheiro \& Suita (2008) consideram os serpentinitos de Liberdade produtos do metamorfismo de porções ofiolíticas. 
Estudos petrográficos (Almeida 1998, 2002) demonstram que tais rochas apresentam uma evolução textural complexa, com crescimento metamórfico de associações de alto grau (olivina+piroxênio) sobre fases hidratadas em ambos os domínios tectônicos definidos para a região por Ribeiro et al. (1990). Contudo, a formação de associações de alto grau apresenta padrões distintos entre as rochas do domínio tectônico da Faixa Brasília e as rochas do domínio tectônico da Faixa Ribeira (Domínios II e III, respectivamente, de acordo com proposta original de Ribeiro).

Em ambos os domínios tectônicos definidos para a região por Ribeiro et al. (1990), as rochas ultramáficas possuem a textura original obliterada pelo crescimento de fases hidratadas. A dependência da disponibilidade de $\mathrm{H}_{2} \mathrm{O}$, cujo acesso é favorecido por processos de deformação, fez com que a hidratação atuasse de forma heterogênea, produzindo desde tipos com cristais ígneos relictos a rochas sem quaisquer vestígios da textura original. Esta fase de hidratação inicial é seguida pela formação de associações de alto grau com crescimento de olivina e piroxênios sobre as fases hidratadas. Por fim, uma nova fase de hidratação, com forte componente metassomático, é registrada nas zonas de contato destes corpos com suas encaixantes. Esta evolução pode ser sintetizada pela seguinte sequência de eventos, observada em ambos os domínios: 1) formação dos protólitos; 2) hidratação; 3) desidratação e, 4) reidratação. A natureza heterogênea destes processos permitiu a coexistência, em muitas rochas, de minerais gerados nos diferentes estágios do metamorfismo (Almeida 1998, 2002). Contudo, apesar das semelhanças na evolução metamórfica dos corpos ultramáficos de ambos os domínios, as rochas destas regiões apresentam padrões distintos entre si, no que diz respeito à evolução das texturas metamórficas e condições físicas de formação das associações de mais alto grau. Estas diferenças são analisadas neste trabalho tendo como base a compatibilidade destas rochas com protólitos ultramáficos e com as reações metamórficas descritas na literatura para este tipo de sistema. Independente da natureza dos protólitos, a ser discutida em uma segunda publicação (Almeida, submetido), o trabalho focaliza a evolução destas rochas durante a formação das associações de mais alto grau, de forma a contribuir na interpretação da história evolutiva desta área.

MATERIAIS E MÉTODOS Foram realizadas análises químicas de minerais de um total de quatorze amostras representativas de ocorrências ultramáficas ao longo do cinturão. $\mathrm{O}$ equipamento usado foi uma microssonda eletrônica JEOL, modelo JXA 8600, contendo cinco espectômetros acoplados a um sistema EDS (Energy Dispersive System) e WDS (Wavelenght
Dispersive System), pertencente ao Instituto de Geociências da USP. O sistema de análise automatizada (Tracor-Northern/Noran Instruments 1990) operou sob corrente do feixe igual a $20 \mathrm{nA}$, diâmetro do feixe igual a $5 \mu \mathrm{m}$ e voltagem de aceleração igual a $15 \mathrm{kV}$. Correções quantitativas $\mathrm{ZAF}\left(\mathrm{Z}=\mathrm{n}^{\circ}\right.$ atômico, $\mathrm{A}=$ absorção, $\mathrm{F}=$ fluorescência) para efeito de matriz foram realizadas por meio do programa Flextrab PLZ, com erro analítico de, aproximadamente, 3\%. Do total de análises, 542 análises foram selecionadas em função de seu fechamento e fórmula estrutural compatíveis com boa qualidade.

Estimativas das condições reinantes de temperatura, nas diversas associações, foram obtidas com base em geotermômetro de Gasparik \& Newton (1984), Wells (1977), Sack \& Ghiorso (1991) e com a aplicação do programa TWQ, desenvolvido por Berman (1991).

O geotermômetro apresentado por Gasparik \& Newton (1984), aplicado a rochas contendo espinélio, baseia-se no conteúdo de $\mathrm{Al}_{2} \mathrm{O}_{3}$ em ortopiroxênio coexistente com olivina e espinélio, definindo a seguinte condição de equilíbrio (equação 1):

$\mathrm{T}\left({ }^{\circ} \mathrm{C}\right)=3857 \mathrm{~K}+443+\mathrm{P}(\mathrm{Kb})$

sendo o cálculo de K fornecido pela equação de Fujii (1977):

$$
\mathrm{K}=\frac{\left(\mathrm{X}_{\mathrm{Al}}^{\mathrm{M} 1}\right)_{O p x^{*}}\left(\mathrm{X}_{\mathrm{Mg}}^{\mathrm{M} 2}\right)^{2}{ }_{\mathrm{ol}}}{\left(\mathrm{X}_{\mathrm{Mg}}^{\mathrm{M} 1}\right)_{O p x} \cdot\left(\mathrm{X}_{\mathrm{Mg}}^{\mathrm{A}}\right)_{S p} \cdot\left(\mathrm{X}_{\mathrm{Al}}^{\mathrm{B}}\right)^{2}}
$$

com as seguintes sugestões para cálculo de $\left(\mathrm{X}_{\mathrm{Al}}{ }^{\mathrm{Ml}}\right)_{O p x} \mathrm{e}$ $\left(\mathrm{X}_{\mathrm{Mg}}{ }^{\mathrm{M} 1}\right)_{\mathrm{Opx}}$ :

$\left(\mathrm{X}_{\mathrm{Al}}^{\mathrm{Ml}}\right)_{\mathrm{Opx}}=\mathrm{X}_{\mathrm{MgTs}_{\mathrm{T}}}+\mathrm{Na}$, com $\mathrm{X}_{\mathrm{MgTs}}=(\mathrm{Al}-\mathrm{Na}-2 \mathrm{Ti}-\mathrm{Cr}) / 2$

$\left(\mathrm{X}_{\mathrm{Mg}}^{\mathrm{M} 1}\right)_{\mathrm{Opx}}=\mathrm{X}_{\mathrm{En}}+\mathrm{Ca}+\mathrm{Mn}$, com $\mathrm{X}_{\mathrm{En}}=\mathrm{Mg}-\mathrm{Ca}-\mathrm{Cr}-$ $\mathrm{Mn}-\mathrm{X}_{\mathrm{MgTs}}$

O geotermômetro de Wells (1977), aplicado às amostras de metawebsterito, tem como base a equação:

7341

$$
\begin{aligned}
& \mathrm{T}\left({ }^{\circ} \mathrm{C}\right)=\frac{}{3,355+2,44 \mathrm{X}_{\mathrm{Fe}}{ }^{\mathrm{opx}}-\ln \mathrm{K}} \\
& \text { sendo } \mathrm{K}=\frac{\left(\mathrm{X}_{\mathrm{Mg}}^{\mathrm{M} 1} \cdot \mathrm{X}_{\mathrm{Mg}}^{\mathrm{M} 2}\right)_{\mathrm{Cpx}}}{\left(\mathrm{X}_{\mathrm{Mg}}^{\mathrm{M} 1} \cdot \mathrm{X}_{\mathrm{Mg}}^{\mathrm{M} 2}\right)_{O p x}}
\end{aligned}
$$

O termômetro de Sack \& Ghiorso (1991) é baseado em trocas iônicas de $\mathrm{Mg}$ e $\mathrm{Fe}$ entre olivina e espinélio, com curvas de imiscibilidade indicando as condições de equilíbrio do par. 
O cruzamento das curvas de equilíbrio de associações mineralógicas em diagrama $P-T$, no programa TQW (Thermobarometry with Estimation of Equilibrium State), de Berman (1991), indicariam as condições favoráveis ao equilíbrio das associações fornecidas.

As seguintes abreviaturas são utilizadas neste trabalho: An (anortita); Ant (antofilita); Anf (anfibólio); Al-anf (anfibólio aluminoso); $\mathrm{Cl}$ (clorita); En (enstatita); Cpx (clinopiroxênio); Di (diopsídio); Fo (forsterita); Gn (granada); Oli (olivina); Opx (ortopiroxênio); Pla (plagioclásio); Tc (talco); Tre (tremolita); Tsh (tschermackita); Serp (serpentina); Sp (espinélio).

As curvas de equilíbrio no sistema $\mathrm{CaO}-\mathrm{MgO}-$ $-\mathrm{Al}_{2} \mathrm{O}_{3}-\mathrm{SiO}_{2}-\mathrm{H}_{2} \mathrm{O}$ (CMASH), $\mathrm{MgO}-\mathrm{SiO}_{2}-\mathrm{H}_{2} \mathrm{O}(\mathrm{MSH})$ e $\mathrm{MgO}-\mathrm{Al}_{2} \mathrm{O}_{3}-\mathrm{SiO}_{2}-\mathrm{H}_{2} \mathrm{O}$ (MASH) utilizadas nas estimativas das condições físicas de formação das associações foram estabelecidas de acordo com trabalhos de Evans (1977), Chernosky et al. (1985), Obata \& Thompson (1981), Jenkins (1983) e Schmädicke \& Evans (1997), que apresentam boa concordância entre si e sintetizam informações desenvolvidas em estudos prévios destes sistemas.

CONTEXTO REGIONAL As rochas estudadas neste trabalho estão localizadas em unidades expostas ao sul do Craton de São Francisco, no domínio da Faixa Brasília. Nesta região, as rochas comporiam um empilhamento metamórfico resultante de uma colisão neoproterozoica entre duas placas, designadas Sanfranciscana e Paranapanema, a primeira de margem passiva e, a segunda, de margem ativa (Campos Neto 2000). A faixa estaria estruturada com base em três domínios tectônicos: 1) Nappe Socorro-Guaxupé, contendo rochas de alta temperatura, relacionadas à raiz de arco-magmático; 2) Terreno Andrelândia, representando um domínio continental subductado sob condições de alta pressão e, 3) Sistema de Nappes Carrancas e Lima Duarte, representando o domínio mais externo de uma margem continental passiva (Campos Neto \& Caby 1999, Campos Neto 2000, Campos Neto et al. 2004, Trouw et al. 2000). A localização da área discutida neste trabalho em relação ao mapa tectônico proposto por estes autores está ilustrada na figura 1.

Paciullo et al. (2000) apresentaram uma estratigrafia da região, estabelecida com base em litofácies e ilustrada na figura 2, onde é possível observar o posicionamento alóctone dos corpos ultramáficos em relação as suas encaixantes.

Alguns autores consideram esta região afetada por uma colisão tardia com a Faixa Ribeira (Trouw et al. 1994, Trouw et al. 2000, Peternel et al. 2005) enquanto outros consideram a possibilidade de um único evento colisional contínuo (Campos Neto \& Caby 2000). Neste contexto, as falhas de empurrão extensas que cortam a região seriam dobradas por fases posteriores, resultando na sobreposição de rochas metassedimentares neoproterozoicas com lentes gnaissicas (Trouw et al. 1986).

Um quadro geral resultante de uma possível interferência entre a Faixa Ribeira e Brasília, foi apresentado por Ribeiro et al. (1990). Na região aqui abordada foram reconhecidos dois domínios tectônicos, o primeiro possuindo padrões estruturais compatíveis com a Faixa Brasília e, o segundo, compondo uma zona onde predominam padrões compatíveis com a Faixa Ribeira (Fig. 3). Pertenceriam ao domínio tectônico da Faixa Brasília as ocorrências ultramáficas situadas entre São Vicente de Minas e Carrancas, estando a primeira situada no contato entre ambos. No domínio tectônico da Faixa Ribeira estariam as ocorrências de Liberdade, Arantina, Andrelândia e Serra da Garça. O modelo de Ribeiro é adotado neste trabalho como sistemática de descrição, com o objetivo de avaliar as características das rochas ultramáficas nestes domínios.

DESCRIÇÃO PETROGRÁFICA No domínio tectônico da Faixa Brasília, predominam rochas ultramáficas hidratadas constituídas por anfibólios, clorita e talco. Rochas com olivina e piroxênios ocorrem na região de São Vicente de Minas (Fazenda Bela Vista) e Carrancas (Fazenda da Areia e Fazenda Rui Barbosa).

Corpos ultramáficos situados no domínio tectônico da Faixa Ribeira exibem maior diversidade de tipos litológicos, em comparação ao domínio da Faixa Brasília. Na região de Liberdade, os corpos da Fazenda da Roseta e do Morro do Corisco são compostos, essencialmente, por serpentinitos com metapiroxenitos, metadunitos e hornblenditos subordinados. As ocorrências da região da Serra da Garça contêm metaortopiroxenito e rochas ricas em talco, antofilita e clorita abundantes. Em Arantina e Andrelândia predominam rochas ricas em minerais hidratados, com uma ocorrência local de serpentinito com grãos de olivina prismáticos. A seguir é apresentada uma análise comparativa entre litotipos contendo associações minerais semelhantes em ambas as regiões. Para descrições detalhadas destas rochas, ver Almeida $(1998,2002)$.

Metapiroxenitos Metapiroxenitos localizados no domínio da Faixa Ribeira se apresentam intensamente deformados exibindo registros de diferentes etapas de sua evolução metamórfica. Em Liberdade, metawebsteritos exibem texturas compatíveis com crescimento metamórfico de clino- e ortopiroxênio sobre a hornblenda da matriz. Segundo Almeida (2002), tal crescimento é concomitante à deformação principal que afetou o corpo. A figura 4 é ilustrativa da heterogeneidade do metamorfismo e da deformação sobre estas rochas. Na sequência 


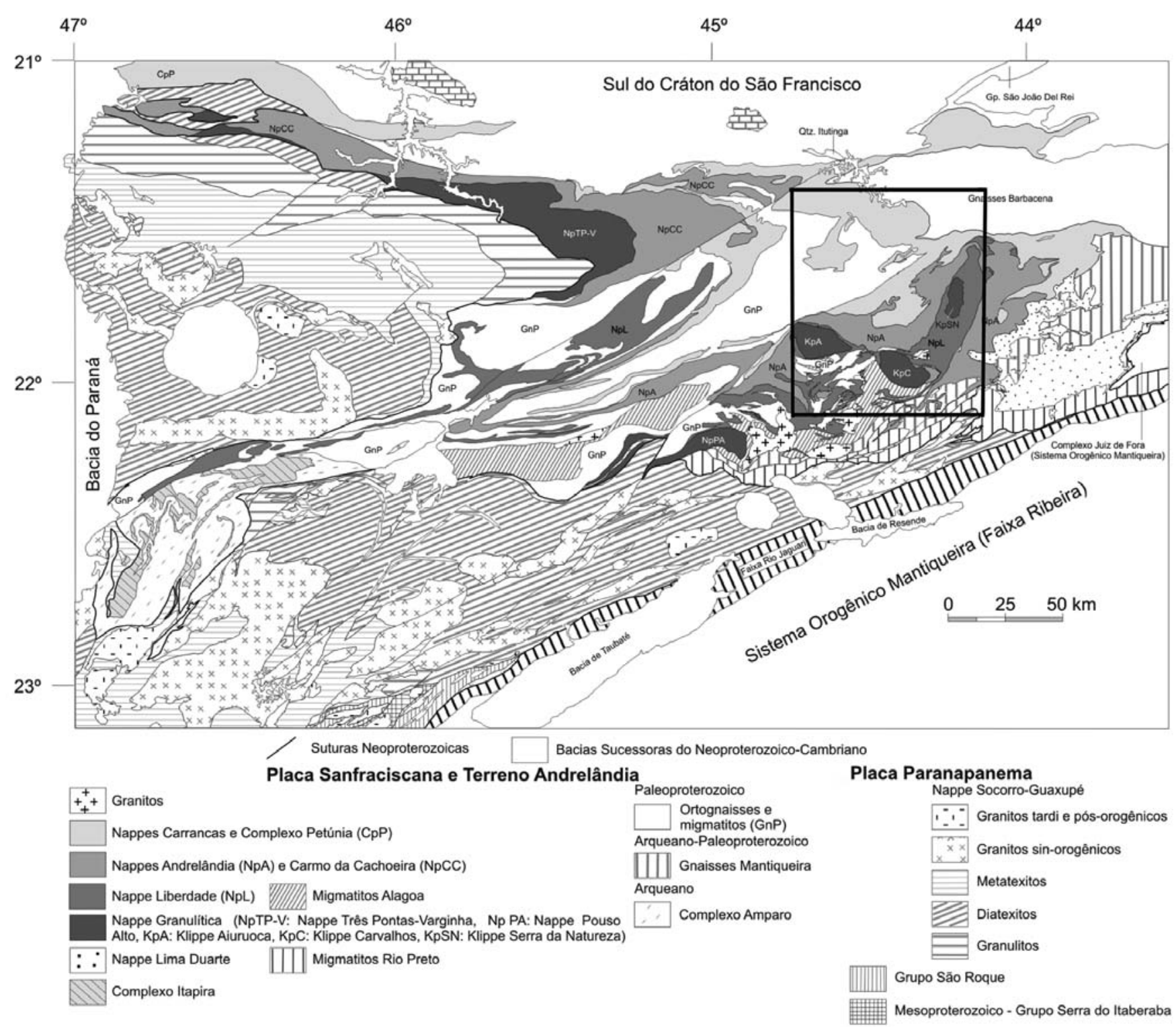

Figura 1 - Mapa Tectônico do Orógeno Brasília Meridional. Extraído de Campos et al. (2007). No destaque, localização da área estudada.

de imagens é possível observar a passagem gradual, em uma mesma rocha, de uma textura granoblástica para uma textura em mosaico. Deformação complexa também é registrada em metaortopiroxenitos da Serra da Garça, onde enstatita, associada à antofilita, olivina e talco também se encontra intensamente deformada.

No domínio tectônico da Faixa Brasília, metapiroxenitos são rochas de granulação grossa, com ortopiroxênio poiquiloblástico contendo inclusões de anfibólio (hornblenda), espinélio aluminoso, olivina e ortopiroxênio de geração anterior. Assim como nos tipos modalmente equivalentes presentes no domínio da Faixa Ribeira (Fig. 5), possui ortopiroxênios com características de crescimento metamórfico, mas sem vestígios de deformação intensa, como a registrada entre os piroxenitos da Faixa Ribeira. Neste caso, a deformação de megacristais se traduz em extinção ondulante e em recristalização ao longo de microzonas de cisalhamento.

Metaperidotitos No domínio da Faixa Ribeira, metaperidotitos são representados por espinélio meta-harzburgito e dunito. Espinélio, no meta-hazburgito, ocorre no contato entre ortopiroxênio e olivina, sob três formas: com textura simplectítica, como cristais granulares, xenoblástico ou como cristais poligonizados. A ocorrência de espinélio na região de contato entre olivina e ortopiroxênio indica formação a partir da reação subsólida entre estes minerais, com expulsão de alumina do piroxênio rico em componente tschermackítico em fase anterior ao processo de poligonização, pois este afeta tanto os espinélios granulares como os espinélios simplectíticos. Estas texturas são compatíveis com nucleação de espinélio 


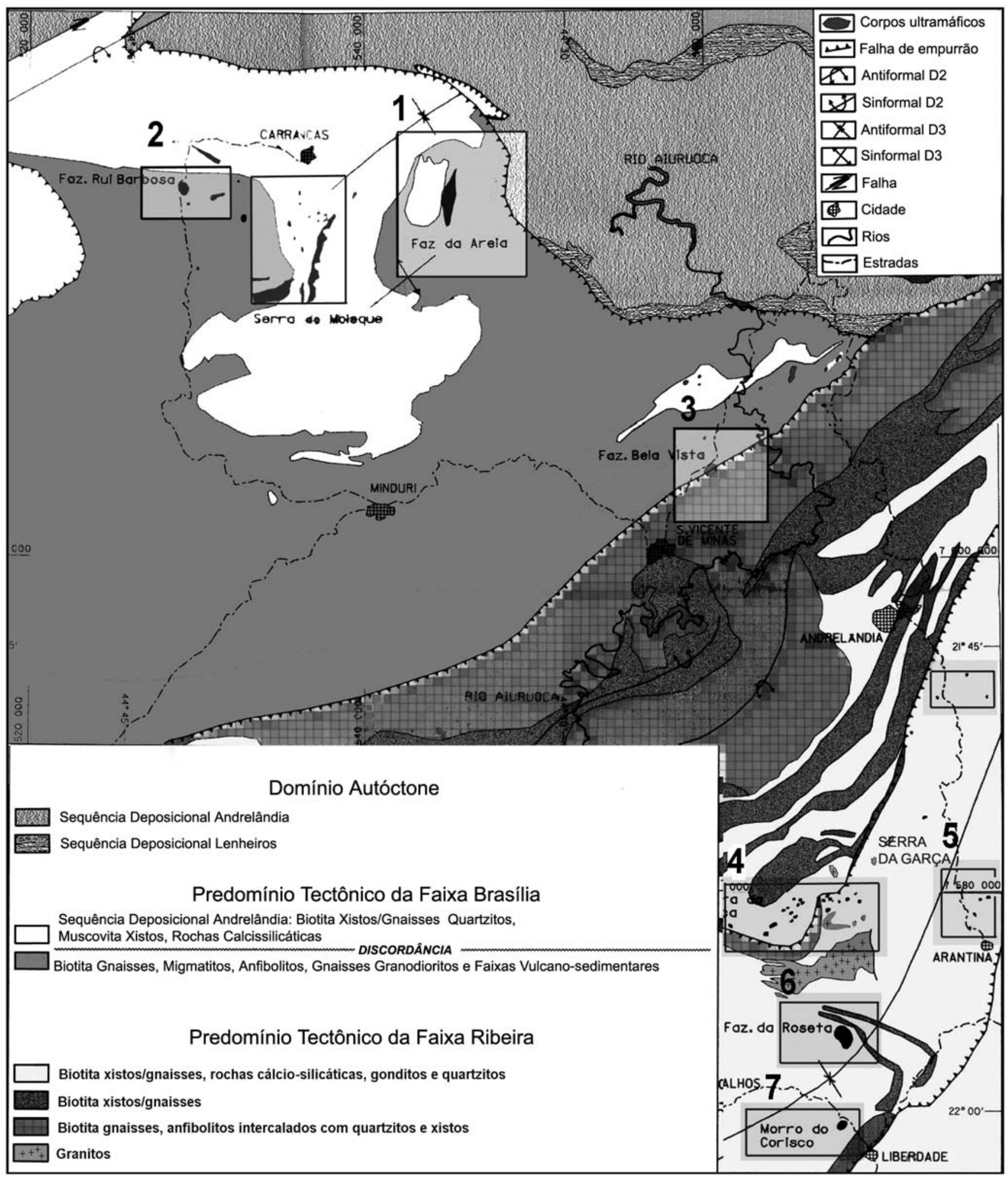

Figura 2 - Ocorrências de rochas ultramáficas na região entre Liberdade e Carrancas. As áreas destacadas indicam os corpos discutidos neste trabalho: (1) Fazenda da Areia, (2) Fazenda Rui Barbosa e Serra do Moleque, (3) Fazenda Algodoal, (4) Serra da Garça, (5) Arantina, (6) Fazenda da Roseta, (7) Morro do Corisco. Dados geológicos por Paciullo et al. (2000). 


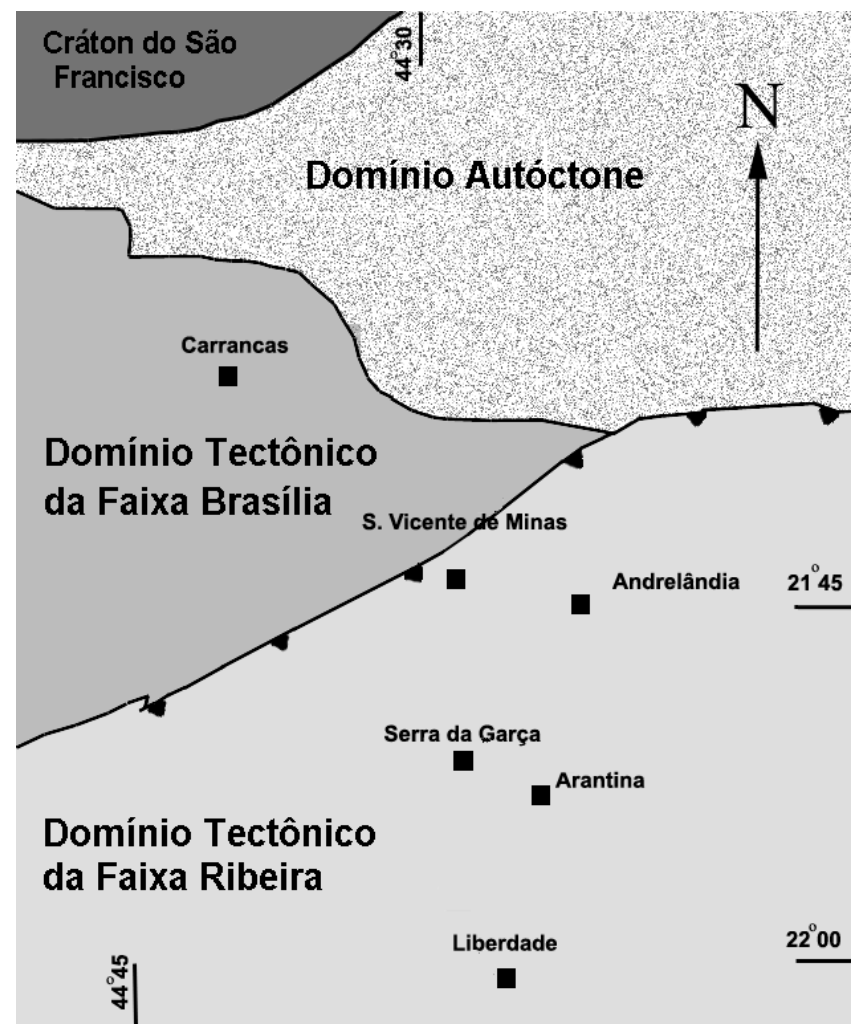

Figura 3 - Localização dos Domínios Tectônicos segundo trabalho original de Ribeiro et al. (1990).

nas bordas dos grãos ao longo de um processo contínuo durante queda de temperatura de forma semelhante aos processos descritos por Hibbard (1995) e Embury \& Nicholson (1965), onde grãos previamente formados adquirem formas compactas, enquanto os grãos tardios exibem textura lamelar. As figuras $6 \mathrm{~A}$ e B são ilustrativas desta evolução textural. Assim como nos metapiroxenitos deste domínio, o meta-harzburgito exibe relictos de ortopiroxênio ígneo, com forte zoneamento composicional associados a ortopiroxênio metamórfico. Dunitos foram identificados no Morro do Corisco por Magalhães (1985), exibindo textura cumulática reliquiar (Fig. 6C).

No domínio tectônico da Faixa Brasília, apenas uma ocorrência de metaperidotito, foi localizada. Esta está localizada no corpo serpentinítico da Fazenda Rui Barbosa, com olivina de hábito tabular entrelaçada com serpentina acicular (Fig. 6D).

Talco xisto e talco fels Rochas ricas em talco são abundantes no domínio tectônico da Faixa Brasília e ocorrem, com pouca frequência, no domínio da Faixa Ribeira onde talco é encontrado como mineral essencial apenas na Serra da Garça, associado à antofilita asbestiforme.

No domínio da Faixa Brasília, rochas contendo misturas de talco e clorita são encontradas ao longo de zonas de cisalhamento que cortam metapiroxenito, enquanto talco xisto e talco fels bastante puros ocorrem bordejando serpentinito e metapiroxenito ou compondo corpos satélites. Esta disposição indica uma origem metassomática (do tipo blackwall) por reação entre as rochas ultramáficas e suas encaixantes ácidas. Carbonato ocorre localmente, de forma subordinada, associada a talco. Desta forma, a presença de talco registra condições metamórficas diferentes em ambos os domínios: na Faixa Ribeira, sua associação com antofilita, define condições de temperatura entre 650 e $850^{\circ} \mathrm{C}$, compatíveis com aquelas indicadas pela associação granada + cianita, presente nas rochas encaixantes, enquanto no domínio da Faixa Brasília, onde talco bordeja serpentinito, sua formação é consequente de reações envolvendo serpentina e sílica (ex., serpentina $+\mathrm{SiO}_{2}=$ talco $+\mathrm{H}_{2} \mathrm{O}$ ), que ocorrem, tipicamente, sob condições de menor temperatura - entre 300 e $350^{\circ} \mathrm{C}$ (Evans 1977, Chernosky et al. 1985).

Anfibólio/clorita xisto e fels Rochas contendo clorita e anfibólios como constituintes essenciais são frequentes no domínio tectônico da Faixa Brasília. Estas ocorrem como tipos bordejantes no corpo piroxenítico da Fazenda da Areia e em vários corpos de dimensões métricas da região, sendo as associações predominantes: anfibólio+talco+clorita; anfibólio+clorita; anfibólio+talco+espinélio e anfibólio+olivina+clorita + minerais opacos. Nas associações com predominância de anfibólio, hornblenda possui textura granoblástica poligonizada, sem nenhum tipo de orientação, mesmo nas amostras xistosas, onde clorita é o mineral responsável pela estruturação da rocha. Em alguns casos, como no corpo tabular da Serra do Moleque, em Carrancas, textura granoblástica sugere substituição pseudomórfica de um protólito cumulático (Fig. 7A). Clorita, com granulometria fina a média, é observada nos planos de clivagem de anfibólio, substituindo suas bordas ou seccionando-o e, nas amostras xistosas, clorita ocorre sob três formas: 1) em bandas milimétricas, onde está fortemente orientada; 2) com disposição aleatória, associada ao anfibólio contido entre estas bandas e, 3 ) ao redor de minerais opacos, envolvendo-os como uma corona. A formação de clorita nestas rochas está, portanto, condicionada a atividades metassomáticas com processos dinâmicos associados a diferentes fases de deformação (Fig. 7B). Na Fazenda Rui Barbosa, clorita xistos ocorrem nas bordas do corpo ultramáfico e ao longo de faixas cisalhadas que cortam o corpo serpentinítico.

$\mathrm{Na}$ área do domínio da Faixa Ribeira compreendida neste estudo, clorita aparece, na maior parte das vezes, como mineral retrometamórfico, em pequena porcentagem. Rochas com clorita abundante são observadas apenas localmente, em auréolas metassomáticas 

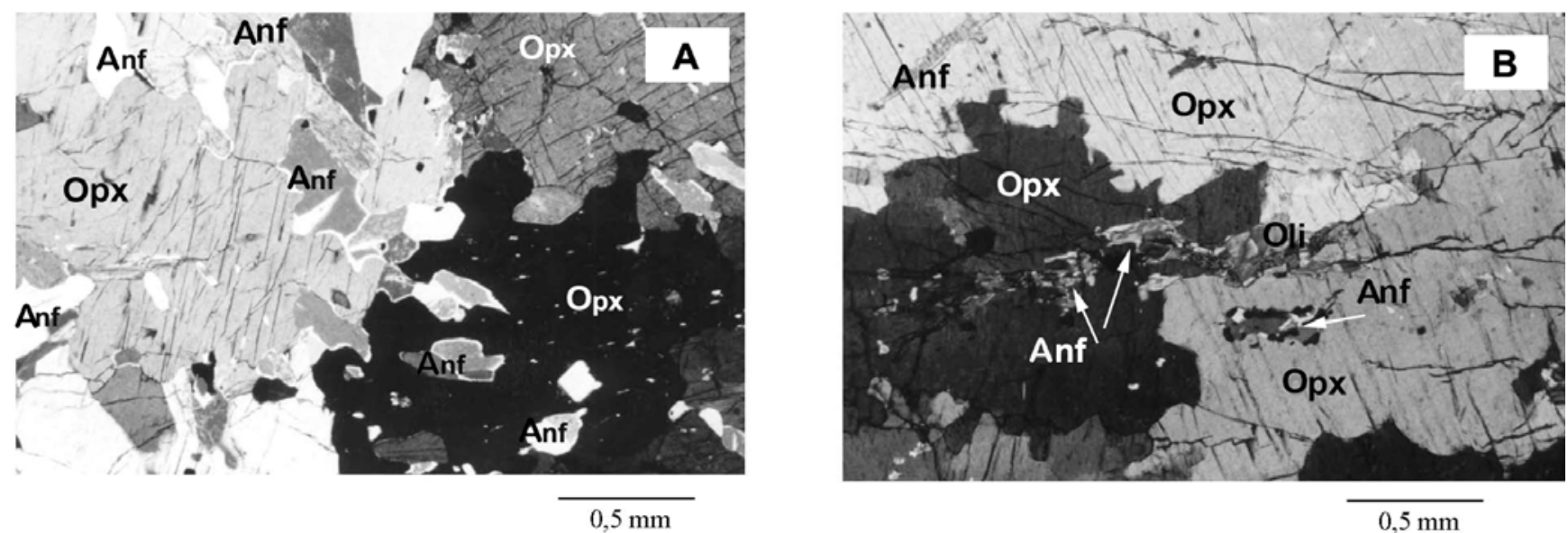

$0.5 \mathrm{~mm}$

$0,5 \mathrm{~mm}$
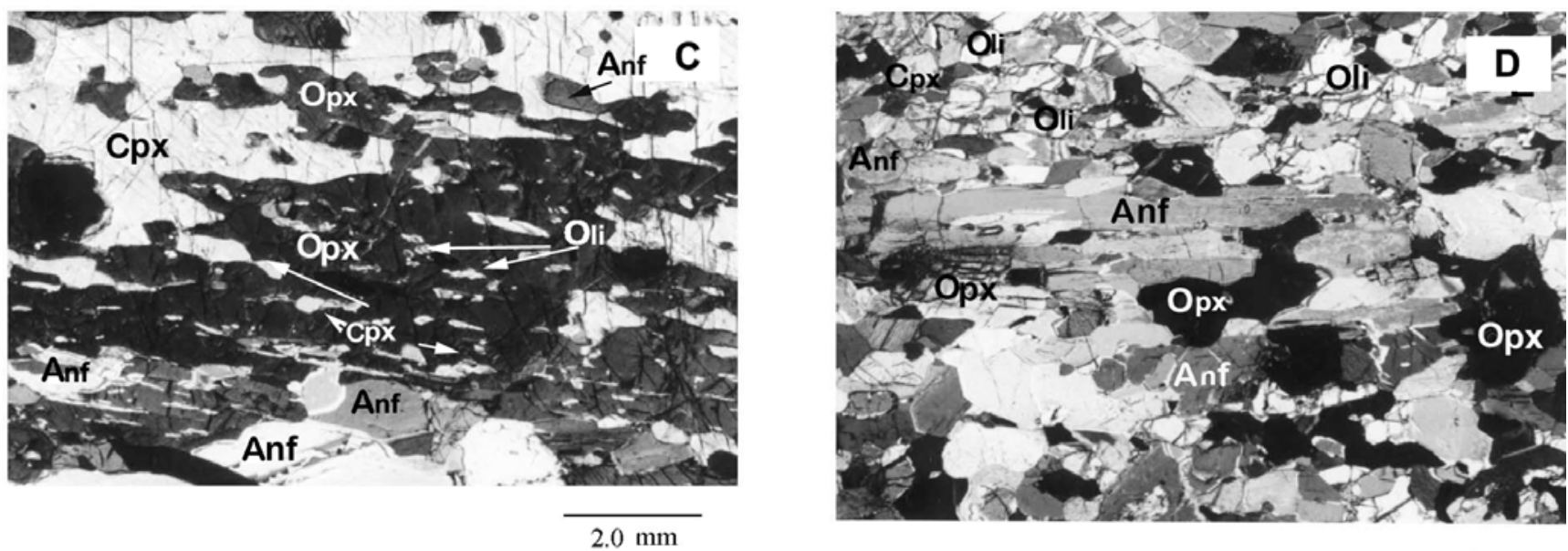

$0,5 \mathrm{~mm}$

Figura 4 - Sequência de deformação em metapiroxenito do domínio tectônico da Faixa Ribeira. Em (A) granoblastos de piroxênios com inclusões de anfibólio; (B) cristais exibem direção preferencial de alongamento; (C) forte orientação dos elementos, com orto e clinopiroxênio interdigitados e (D): poligonização da associação.
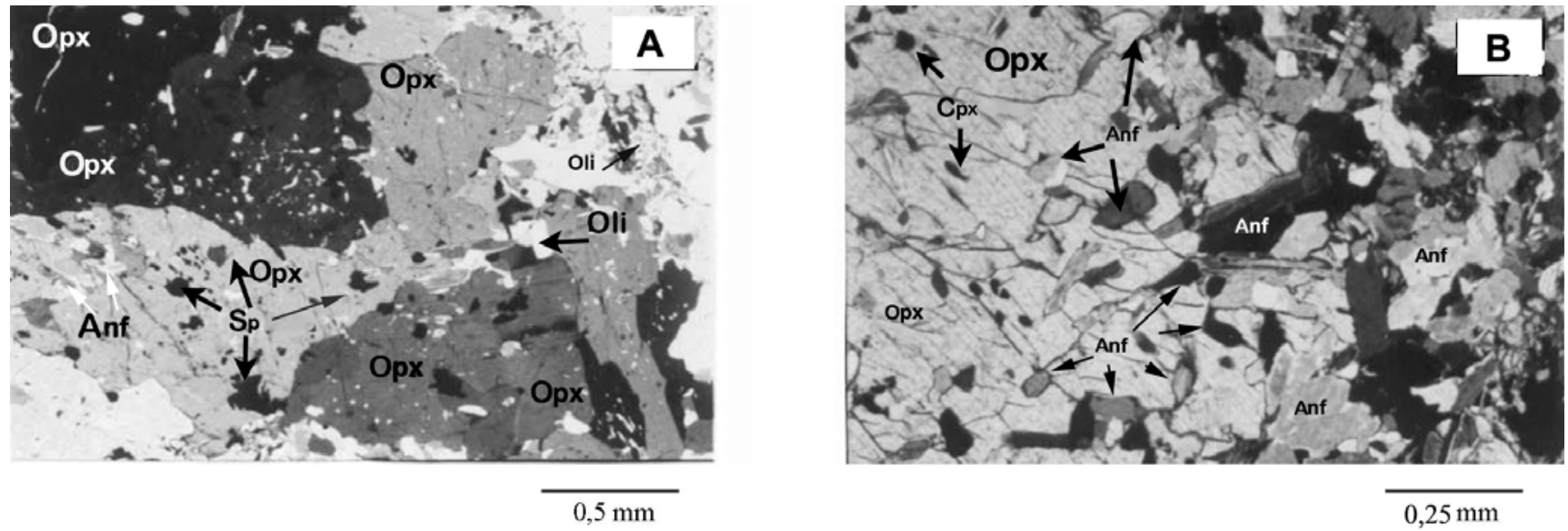

Figura 5 - Metapiroxenito associado ao domínio tectônico da Faixa Brasília: (A) blastos indeformados de ortopiroxênio que sobrecrescem matriz de anfibólio e espinélio; (B): detalhe da figura 5 A. 
(blackwall), com poucos centímetros de extensão, localizadas entre as rochas ultramáficas e suas encaixantes. Na Serra da Garça e nas exposições situadas entre Arantina e Andrelândia, a associação clorita+anfibólio predomina em ocorrências não foliadas, de dimensões métricas. Em Arantina, um dos afloramentos possui clorita associada à olivina metamórfica de hábito tabular com inclusões de olivina de origem pretérita. Esta rocha não apresenta serpentina e possui olivina texturalmente equilibrada com tremolita e com crescimento topoaxial de clorita em relação à olivina. $\mathrm{Na}$ Serra da Garça e na região entre Arantina e Andrelândia, antofilita está associada à olivina e ortopiroxênio (Figs. 7C e D), compondo fels.

Serpentinito Corpos de serpentinito de ambos os domínios exibem aspectos contrastantes. No domínio da Faixa Ribeira, as ocorrências possuem contornos ovalados e suas rochas apresentam aspecto poroso e brilho silicoso, quebrando-se ao longo de superfícies irregulares, sob a forma de pequenos blocos, enquanto no domínio tectônico da Faixa Brasília, a maioria dos serpentinitos está exposta em corpos alongados de extensão quilométrica sugestiva de uma origem como sills. Tais rochas quebram-se sob a forma de lascas, com superfícies mais regulares e lisas. Tais diferenças encontram reflexos a nível microscópico: serpentinitos inseridos no domínio da Faixa Ribeira exibem textura "mesh" (Fig. 7E), com olivina e piroxênios reliquiares indicando um protólito originalmente granular, enquanto, no domínio tectônico da Faixa Brasília, serpentina ocorre em agregados tabulares de granulometria variável, compondo foliações ou entrelaçadas (Fig. 7F). Os tipos vão de serpentinitos puros a associações contendo hornblenda, clorita e talco em menores proporções.

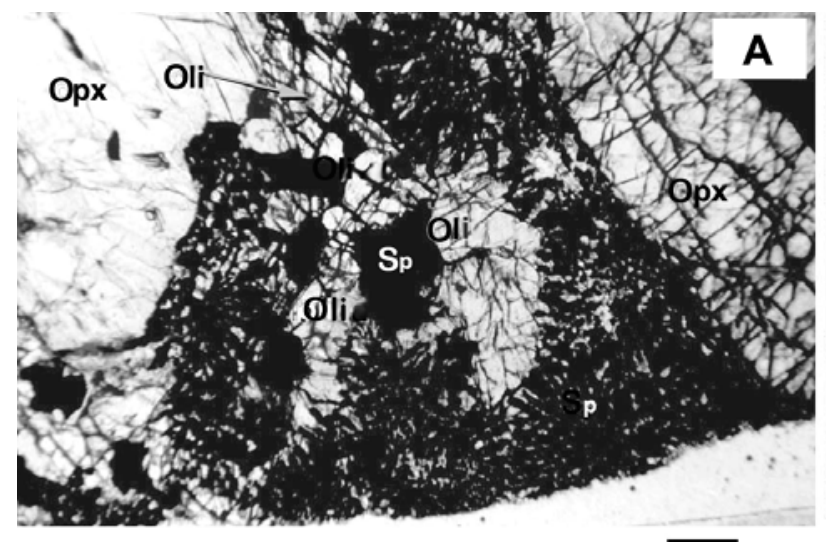

$1,0 \mathrm{~mm}$

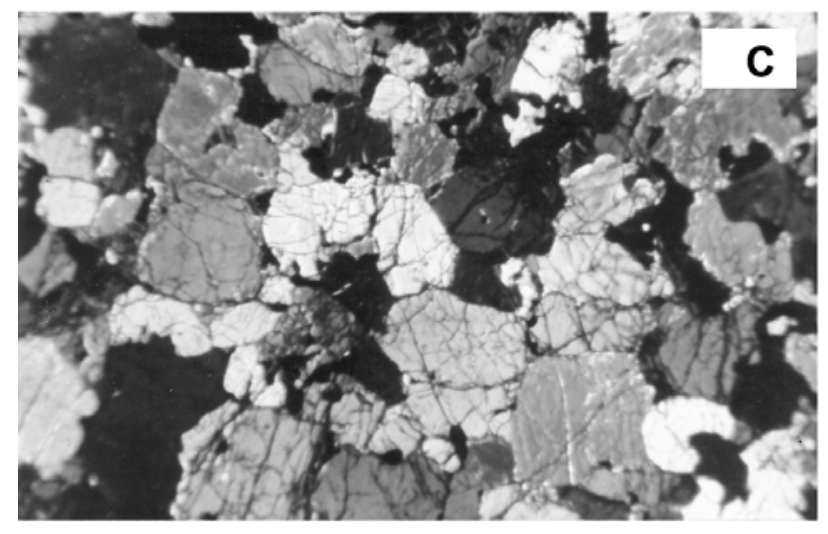

$1,0 \mathrm{~mm}$
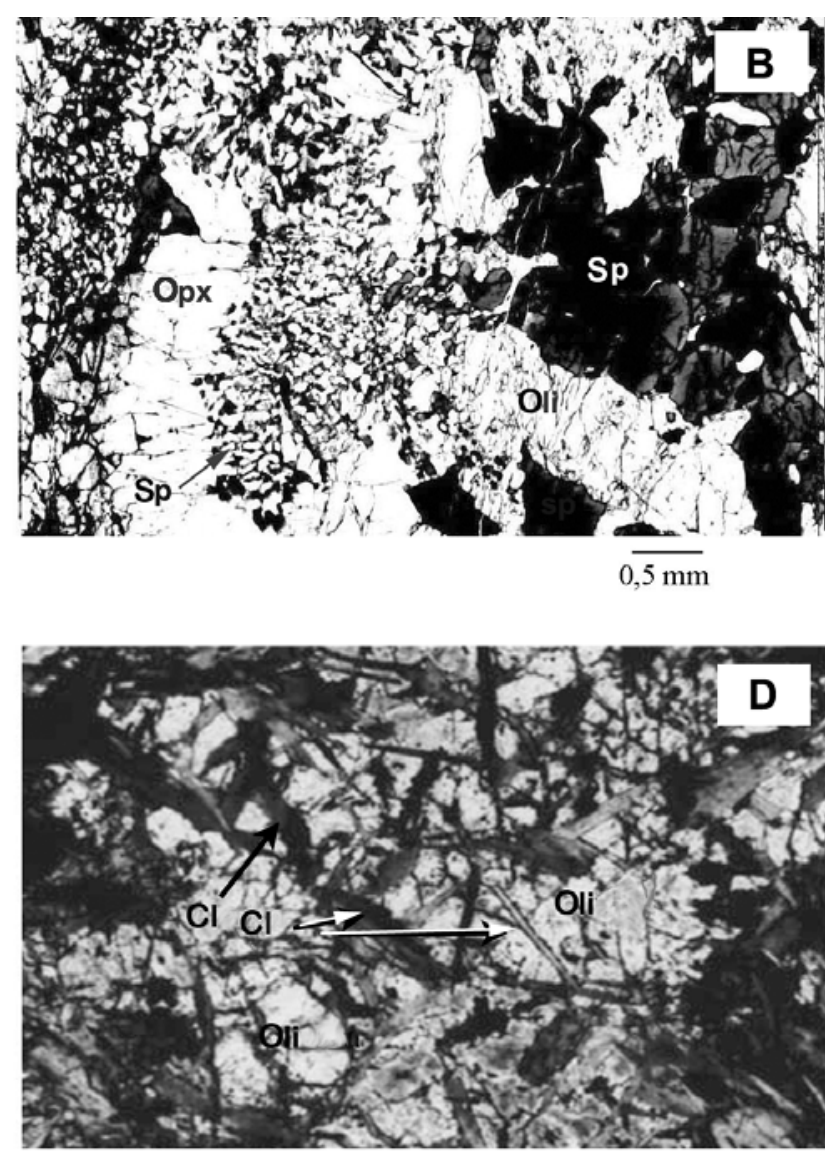

$0,25 \mathrm{~mm}$

Figura 6 - Metaperidotitos do domínio tectônico da Faixa Ribeira: (A) Espinélio simplectítico no contato entre ortopiroxênio e olivina em meta-harzburgito. (B)Variação textural do espinélio em meta-hazrburgito. À esquerda, espinélio com textura simplectítica, à direita, espinélio granular. (C) Dunito com textura adcumulática reliquiar em amostra descrita por Magalhães (1985). Figura 6D: único exemplar peridotítico do domínio tectônico da Faixa Brasília: olivina em porção metadunítica do corpo serpentinítico da Fazenda Rui Barbosa, Carrancas. 

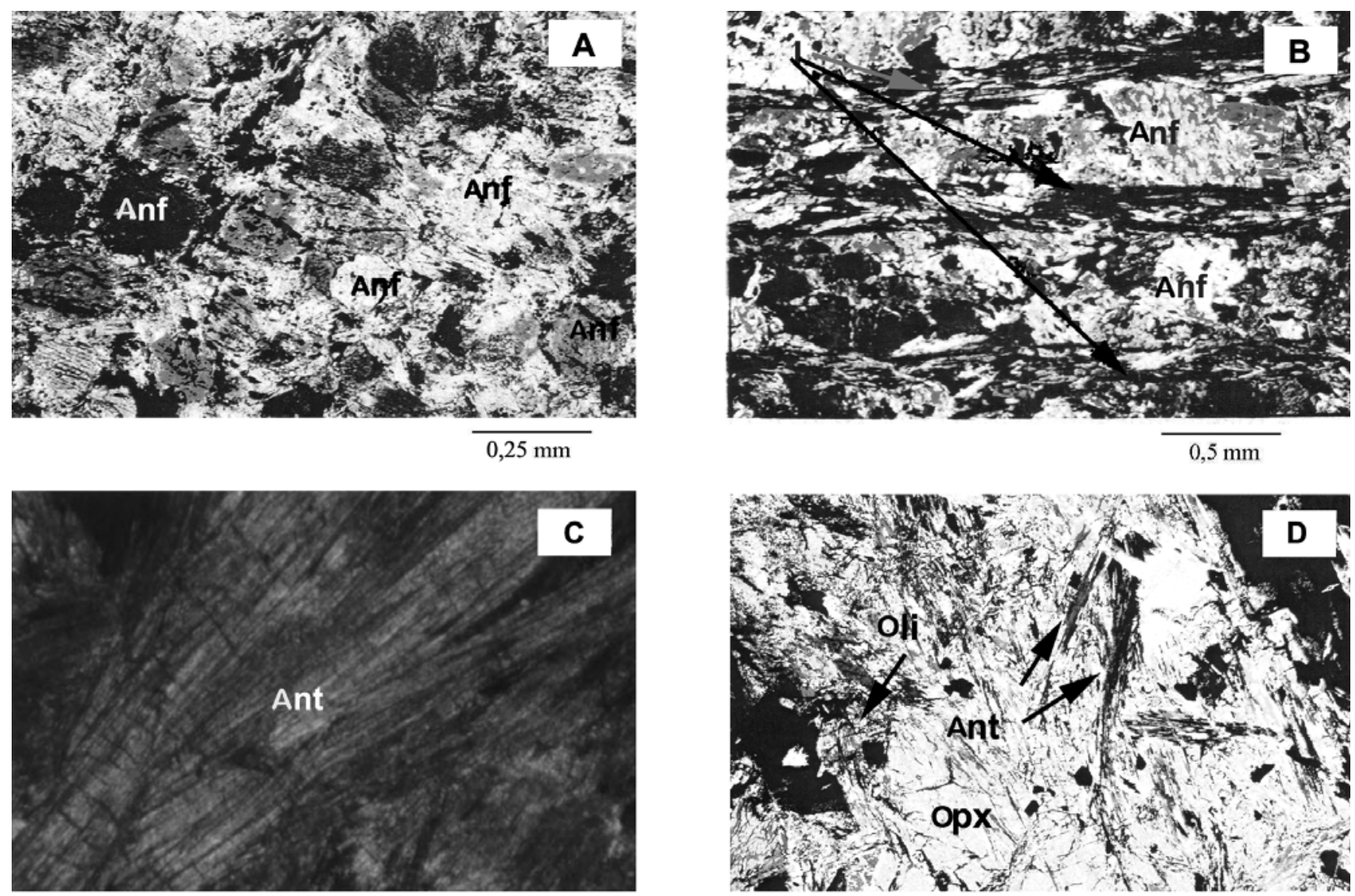

$0,5 \mathrm{~mm}$

$0,5 \mathrm{~mm}$

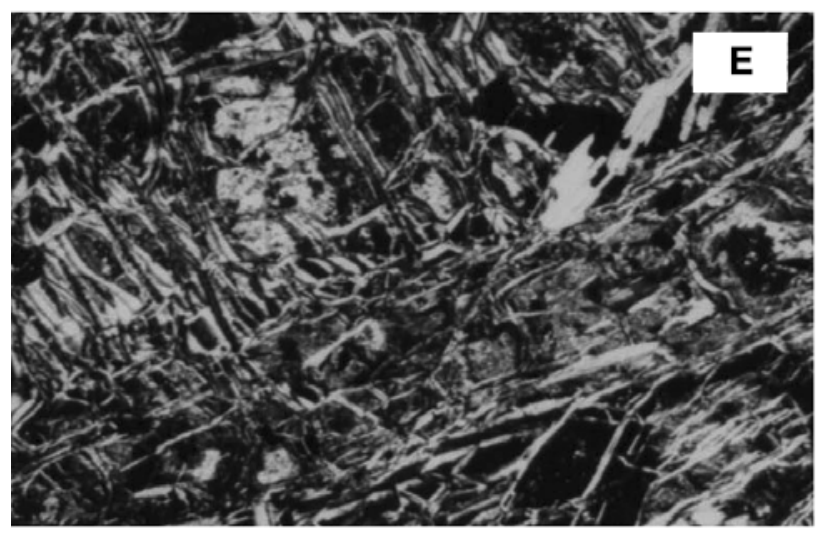

$0,5 \mathrm{~mm}$

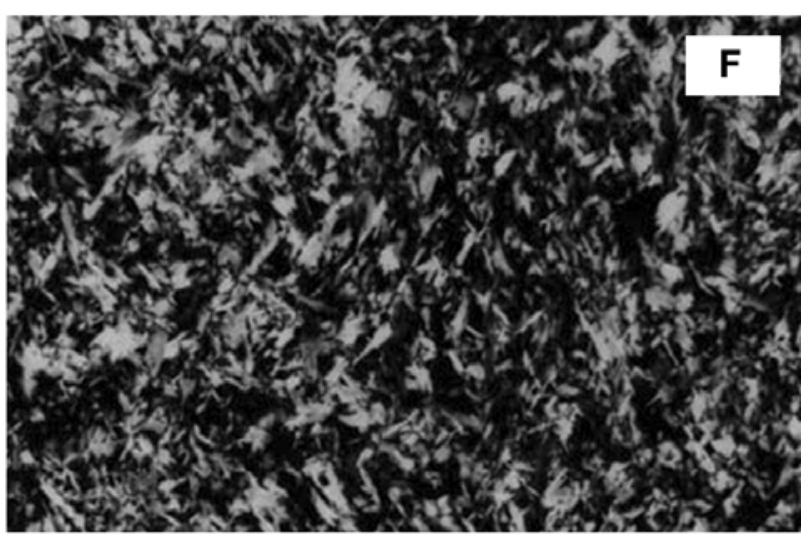

$0,5 \mathrm{~mm}$

Figura 7 - Texturas em rochas ultramáficas constituídas essencialmente por minerais hidratados. (A, B): exemplares do domínio tectônico da Faixa Brasília. Em (A) hornblendito granoblástico com textura sugestiva de pseudomorfose de protólito cumulático, em (B) foliação definida por clorita ao longo de microcisalhamentos. (C, D, E): exemplares do domínio tetônico da Faixa Ribeira. Em C e D, antofilita fibrosa associada à ortopiroxênio. As imagens (E) e (F) ilustram o contraste textural entre serpentinitos de ambos os domínios: textura “mesh” no domínio da Faixa Ribeira (E) e placoide no domínio tectônico da Faixa Brasília (F).

QUÍMICA MINERAL A tabela 1 apresenta a relação de rochas e fases minerais analisadas. Análises representativas das diferentes fases estão listadas nas tabelas 2 (ortopiroxênio), 3 (clinopiroxênio), 4 (espinélio), 5 (olivina) e 6 (anfibólio).
A variação do conteúdo de En em ortopiroxênios é restrita, entre $\mathrm{En}_{85}$ e $\mathrm{En}_{91,2}$, nas rochas do Domínio Ribeira e entre $\mathrm{En}_{75}$ e $\mathrm{En}_{85}$ nas rochas do Domínio Brasília. A homogeneidade relativa destes piroxênios pode ser observada no diagrama En-Wo-Fs (Fig. 8) onde 
Tabela 1 - Relação de rochas e respectivas fases minerais analisadas.

\begin{tabular}{|c|c|c|c|}
\hline Localizaçao na Figura 2 & Tipo Petrográfico & Amostra & Minerais analisados \\
\hline \multicolumn{4}{|c|}{ DOMÍNIO DA FAIXA RIBEIRA } \\
\hline \multirow{3}{*}{ Fazenda da Roseta (6) } & Metawebsterito & SO11GB, SO11GB2, FR4 & $\begin{array}{l}\text { ortopiroxênio, olivina, espinélio, anfibólio, } \\
\text { clinopiroxênio }\end{array}$ \\
\hline & Meta-harzburgito & SO11, SO11E, SO11D & ortopiroxênio, olivina, espinélio, clorita \\
\hline & Serpentinito & FR3A & olivina, anfibólio \\
\hline Arantina (5) & Clorita/anfibólio olivina fels & AR, AR1 & olivina, clorita, anfibólio \\
\hline Serra da Garça (4) & Metaortopiroxenito & $\mathrm{SG}, \mathrm{SG} 2 \mathrm{~B}$ & ortopiroxênio, olivina, anfibólio, clorita \\
\hline Morro do Corisco (7) & Serpentinito & $\mathrm{MC}$ & olivina \\
\hline \multicolumn{4}{|c|}{ DOMÍNIO DA FAIXA BRASÍLIA } \\
\hline Fazenda da Areia (1) & $\begin{array}{l}\text { Espinélio-olivina } \\
\text { metaortopiroxenito }\end{array}$ & CA10B, FA-IV & ortopiroxênio, olivina, anfibólio \\
\hline Fazenda Rui Barbosa (2) & Serpentinito & CA7B & olivina \\
\hline Fazenda Bela Vista (3) & $\begin{array}{l}\text { Espinélio-olivina } \\
\text { metaortopiroxenito }\end{array}$ & SV, SV3A & ortopiroxênio, olivina, anfibólio, clorita \\
\hline
\end{tabular}

Tabela 2 - Análises químicas representativas de ortopiroxênio.

\begin{tabular}{|c|c|c|c|c|c|c|c|c|c|c|c|c|c|c|}
\hline Análise & $\mathrm{SiO}_{2}$ & $\mathrm{TiO}_{2}$ & $\mathrm{Al}_{2} \mathrm{O}_{3}$ & $\mathrm{Cr}_{2} \mathrm{O}_{3}$ & MnO & FeO & MgO & NiO & $\mathrm{CaO}$ & $\mathrm{Na}_{2} \mathrm{O}$ & $\mathbf{K}_{2} \mathbf{O}$ & BaO & Total & $\%$ En \\
\hline \multicolumn{15}{|c|}{ DOMÍNIO TECTÔNICO DA FAIXA RIBEIRA } \\
\hline \multicolumn{15}{|c|}{ Metaespinélio harzburgito - Fazenda da Roseta } \\
\hline SO11D20L11 & 57,40 & 0,01 & 1,23 & 0,01 & 0,22 & 9,00 & 31,49 & 0,00 & 0,11 & 0,09 & 0,00 & 0,00 & 99,56 & 85,7 \\
\hline SO11D31L11 & 57,43 & 0,00 & 2,44 & 0,06 & 0,07 & 8,78 & 30,92 & 0,00 & 0,09 & 0,04 & 0,00 & 0,00 & 99,83 & 85,9 \\
\hline SO11E83L7 & 55,71 & 0,00 & 3,4 & 0,02 & 0,06 & 8,89 & 32,11 & 0,00 & 0,2 & 0,00 & 0,02 & 0,07 & 100,48 & 86,1 \\
\hline SO11E89L7 & 54,32 & 0,08 & 3,87 & 0,02 & 0,00 & 8,76 & 32,95 & 0,11 & 0,11 & 0,00 & 0,00 & 0,00 & 100,22 & 87,2 \\
\hline SO1168L11 & 55,81 & 0,05 & 2,72 & 0,00 & 0,08 & 8,86 & 31,61 & 0,03 & 0,25 & 0,02 & 0,00 & 0,04 & 99,47 & 85,9 \\
\hline SO1170L11 & 56,74 & 0,08 & 2,79 & 0,04 & 0,12 & 8,49 & 30,8 & 0,02 & 0,03 & 0,00 & 0,01 & 0,04 & 99,16 & 86,4 \\
\hline SO11E22L5 & 57,00 & 0,00 & 0,03 & 0,00 & 0,16 & 9,58 & 33,6 & 0,00 & 0,18 & 0,00 & 0,00 & 0,00 & 100,45 & 87,9 \\
\hline SO11E20L7 & 57,89 & 0,03 & 0,61 & 0,00 & 0,08 & 7,92 & 33,74 & 0,05 & 0,22 & 0,00 & 0,02 & 0,00 & & 86,6 \\
\hline \multicolumn{15}{|c|}{ Metawebsterito - Fazenda da Roseta } \\
\hline 11GB226L9 & 55,39 & 0,03 & 3,03 & 0,08 & 0,1 & 8,81 & 32,51 & 0,13 & 0,24 & 0,05 & 0,02 & 0,00 & 99,57 & 87,6 \\
\hline 11GB251L9 & 57,53 & 0,00 & 1,07 & 0,03 & 0,05 & 7,46 & 33,77 & 0,07 & 0,25 & 0,00 & 0,02 & 0,00 & 100,25 & 88,5 \\
\hline 11GB257L9 & 56,48 & 0,05 & 2,42 & 0,01 & 0,1 & 7,55 & 33,24 & 0,11 & 0,19 & 0,03 & 0,03 & 0,08 & 100,29 & 88,2 \\
\hline 11GB6L3 & 55,35 & 0,00 & 1,99 & 0,00 & 0,01 & 9,11 & 33,15 & 0,00 & 0,16 & 0,02 & 0,00 & 0,00 & 99,79 & 86,3 \\
\hline 11GB23L3 & 55,77 & 0,00 & 1,64 & 0,00 & 0,02 & 8,6 & 33,6 & 0,13 & 0,00 & 0,00 & 0,00 & 0,00 & 99,76 & 86,2 \\
\hline 11GB56L3 & 55,36 & 0,00 & 1,41 & 0,00 & 0,11 & 9,03 & 33,69 & 0,00 & 0,26 & 0,00 & 0,00 & 0,00 & 99,86 & 87,2 \\
\hline FR472L2 & 54,71 & 0,00 & 1,87 & 0,50 & 0,13 & 9,22 & 32,99 & 0,13 & 0,23 & 0,05 & 0,04 & 0,00 & 99,87 & 85,9 \\
\hline FR470L2 & 54,18 & 0,02 & 2,63 & 0,13 & 0,11 & 7,88 & 34,84 & 0,11 & 0,31 & 0,06 & 0,03 & 0,00 & 100,3 & 88,1 \\
\hline \multicolumn{15}{|c|}{ Metaortopiroxenito - Serra da Garça } \\
\hline SG2B10L4 & 58,51 & 0,00 & 0,04 & 0,00 & 0,00 & 6,25 & 35,21 & 0,00 & 0,00 & 0,00 & 0,00 & 0,00 & 100,01 & 90,9 \\
\hline SG2B12L4 & 59,01 & 0,02 & 0,00 & 0,00 & 0,00 & 6,1 & 35,55 & 0,00 & 0,00 & 0,00 & 0,00 & 0,00 & 100,68 & 91,2 \\
\hline SG2B13L4 & 58,99 & 0,00 & 0,00 & 0,00 & 0,00 & 6,65 & 35,21 & 0,00 & 0,00 & 0,00 & 0,00 & 0,00 & 100,85 & 90,4 \\
\hline SG2B1L4 & 57,79 & 0,00 & 0,00 & 0,00 & 0,00 & 6,54 & 35,36 & 0,00 & 0,00 & 0,00 & 0,00 & 0,00 & 99,69 & 90,6 \\
\hline
\end{tabular}

continua... 
Tabela 2 - Continuação.

\begin{tabular}{|c|c|c|c|c|c|c|c|c|c|c|c|c|c|c|}
\hline Análise & $\mathrm{SiO}_{2}$ & $\mathrm{TiO}_{2}$ & $\mathrm{Al}_{2} \mathrm{O}_{3}$ & $\mathrm{Cr}_{2} \mathrm{O}_{3}$ & MnO & $\mathrm{FeO}$ & MgO & $\mathrm{NiO}$ & $\mathrm{CaO}$ & $\mathrm{Na}_{2} \mathrm{O}$ & $\mathrm{K}_{2} \mathrm{O}$ & $\mathrm{BaO}$ & Total & $\%$ En \\
\hline \multicolumn{15}{|c|}{ DOMÍNIO TECTÔNICO DA FAIXA RIBEIRA } \\
\hline \multicolumn{15}{|c|}{ Metaortopiroxenito - Serra da Garça } \\
\hline SG2B23L4 & 59,08 & 0,00 & 0,17 & 0,00 & 0,02 & 6,00 & 35,06 & 0,00 & 0,00 & 0,00 & 0,01 & 0,00 & 100,34 & 91,2 \\
\hline SG2B25L4 & 58,69 & 0,00 & 0,02 & 0,00 & 0,00 & 6,13 & 35,02 & 0,00 & 0,00 & 0,00 & 0,00 & 0,00 & 99,86 & 91,0 \\
\hline SG2B1L11 & 59,19 & 0,04 & 0,12 & 0,00 & 0,04 & 6,75 & 33,21 & 0,00 & 0,09 & 0,07 & 0,02 & 0,12 & 99,65 & 89,6 \\
\hline SG2B2L11 & 58,96 & 0,00 & & 0,01 & 0,07 & 6,58 & 33,19 & 0,08 & 0,09 & 0,00 & 0,01 & 0,00 & 99,17 & 89,7 \\
\hline \multicolumn{15}{|c|}{ DOMÍNIO TECTÔNICO DA FAIXA BRASÍLIA } \\
\hline \multicolumn{15}{|c|}{ Metaespinélio ortopiroxenito - Carrancas } \\
\hline CA10B21L2 & 55,14 & 0,02 & 2,29 & 0,12 & 0,25 & 15,22 & 26,56 & 0,01 & 0,17 & 0,06 & 0,05 & 0,00 & 99,89 & 75,1 \\
\hline CA10B25L2 & 53,97 & 0,06 & 2,22 & 0,03 & 0,2 & 14,71 & 28,78 & 0,11 & 0,13 & 0,04 & 0,00 & 0,00 & 100,25 & 77,2 \\
\hline CA28L2 & 52,05 & 0,02 & 2,26 & 0,04 & 15,84 & 0,03 & 15,84 & 28,78 & 0,24 & 0,08 & 0,04 & 0,00 & 99,65 & 77,3 \\
\hline FA-IV38L10 & 55,56 & 0,00 & 1,91 & 0,08 & 0,28 & 13,31 & 28,08 & 0,06 & 0,19 & 0,00 & 0,00 & 0,00 & 99,47 & 78,3 \\
\hline FA-IV44L10 & 55,98 & 0,05 & 1,99 & 0,00 & 0,01 & 12,96 & 28,25 & 0,12 & 0,18 & 0,03 & 0,01 & 0,00 & 99,31 & 79,6 \\
\hline FA-IV10L10 & 55,77 & 0,07 & 1,98 & 0,01 & 0,27 & 13,00 & 28,27 & 0,07 & 0,2 & 0,01 & 0,00 & 0,04 & 99,69 & 78,8 \\
\hline FA-IV11L10 & 55,49 & 0,05 & 2,12 & 0,02 & 0,39 & 14,3 & 27,36 & 0,07 & 0,21 & 0,02 & 0,00 & 0,00 & 100,03 & 76,5 \\
\hline FA-IV21L10 & 55,54 & 0,02 & 2,14 & 0,07 & 0,25 & 13,45 & 28,28 & 0,06 & 0,20 & 0,00 & 0,00 & 0,00 & 100,01 & 78,8 \\
\hline \multicolumn{15}{|c|}{ Metaespinélio ortopiroxenito - São Vicente de Minas } \\
\hline SV3A 86L11 & 55,52 & 0,03 & 1,83 & 0,2 & 0,29 & 9,45 & 31,32 & 0,04 & 0,2 & 0,53 & 0,02 & 0,12 & 99,67 & 84,7 \\
\hline SV3A76L11 & 56,21 & 0,07 & 1,83 & 0,04 & 0,26 & 10,07 & 30,49 & 0,00 & 0,18 & 0,00 & 0,00 & 0,00 & 99,15 & 83,7 \\
\hline SV3A77L11 & 56,55 & 1,96 & 0,1 & 0,23 & 10,18 & 30,48 & 0,1 & 0,2 & 0,08 & 0,03 & 0,00 & 0,00 & 99,91 & 83,6 \\
\hline SV3A109L11 & 57,13 & 0,07 & 2,36 & 0,00 & 0,21 & 9,92 & 30,21 & 0,00 & 0,19 & 0,01 & 0,01 & 0,00 & 100,11 & 83,9 \\
\hline SV3A100L11 & 56,47 & 0,00 & 2,06 & 0,06 & 0,27 & 9,94 & 31,25 & 0,09 & 0,18 & 0,01 & 0,01 & 0,00 & 100,34 & 84,2 \\
\hline SV3A113L11 & 55,88 & 0,08 & 1,48 & 0,15 & 0,25 & 9,96 & 31,72 & 0,08 & 0,12 & 0,05 & 0,00 & 0,21 & 99,98 & 84,5 \\
\hline SV3A115L11 & 56,80 & 0,00 & 1,94 & 0,12 & 0,19 & 9,85 & 31,06 & 0,08 & 0,13 & 0,07 & 0,00 & 0,11 & 100,35 & 84,4 \\
\hline SV23A116L11 & 56,73 & 0,03 & 2,23 & 0,09 & 0,16 & 9,49 & 30,74 & 0,02 & 0,14 & 0,00 & 0,03 & 0,00 & 99,70 & 84,8 \\
\hline
\end{tabular}

Tabela 3 - Análises químicas representativas de clinopiroxênio.

\begin{tabular}{|c|c|c|c|c|c|c|c|c|c|c|c|c|c|c|c|c|}
\hline \multicolumn{2}{|c|}{ Análise } & $\mathrm{SiO}_{2}$ & $\mathrm{TiO}_{2}$ & $\mathrm{Al}_{2} \mathrm{O}_{3}$ & $\mathrm{Cr}_{2} \mathrm{O}_{3}$ & FeO & MnO & $\mathrm{NiO}$ & MgO & $\mathrm{CaO}$ & $\mathrm{Na}_{2} \mathrm{O}$ & $\mathrm{K}_{2} \mathrm{O}$ & Total & $\begin{array}{c}\% \\
\text { Wo }\end{array}$ & $\begin{array}{c}\% \\
\text { En }\end{array}$ & $\begin{array}{l}\% \\
\text { Fs }\end{array}$ \\
\hline \multicolumn{17}{|c|}{ DOMÍNIO TECTÔNICO DA FAIXA RIBEIRA } \\
\hline \multicolumn{17}{|c|}{ Metawebsterito - Fazenda da Roseta } \\
\hline $\begin{array}{l}\text { FR } \\
4 \mathrm{~A}\end{array}$ & $\begin{array}{l}64 \\
\text { L2 }\end{array}$ & 51,2 & 0,02 & 1,73 & 0,01 & 2,58 & 0,1 & 0,1 & 17,67 & 26,31 & 0,05 & 0,00 & 99,77 & 49,6 & 46,4 & 4,0 \\
\hline $\begin{array}{l}\text { FR } \\
4 \mathrm{~A}\end{array}$ & $\begin{array}{l}65 \\
\text { L2 }\end{array}$ & 52,43 & 0,07 & 1,73 & 0,17 & 2,68 & 0,07 & 0,07 & 16,83 & 26,47 & 0,05 & 0,01 & 100,58 & 50,9 & 45,0 & 4,1 \\
\hline $\begin{array}{l}\text { FR } \\
4 \mathrm{~A}\end{array}$ & $\begin{array}{l}66 \\
\text { L2 }\end{array}$ & 53,33 & 0,21 & 1,76 & 0,12 & 2,62 & 0,00 & 0,00 & 15,61 & 26,26 & 0,04 & 0,01 & 99,96 & 52,5 & 43,4 & 4,1 \\
\hline $\begin{array}{l}\text { FR } \\
4 \mathrm{~A}\end{array}$ & $\begin{array}{l}68 \\
\text { L2 } \\
\end{array}$ & 52,53 & 0,00 & 1,81 & 0,20 & 2,83 & 0,00 & 0,00 & 16,59 & 26,15 & 0,03 & 0,04 & 100,18 & 50,8 & 44,9 & 4,3 \\
\hline $\begin{array}{l}\text { FR } \\
4 \mathrm{~A} \\
\end{array}$ & $\begin{array}{l}71 \\
\text { L2 } \\
\end{array}$ & 52,71 & 0,05 & 1,86 & 0,11 & 2,81 & 0,00 & 0,05 & 15,89 & 26,82 & 0,04 & 0,02 & 100,36 & 52,5 & 43,2 & 4,3 \\
\hline $\begin{array}{c}11 \\
\text { GB2 }\end{array}$ & $\begin{array}{c}5 \\
\text { L3 }\end{array}$ & 52,43 & 0,00 & 1,66 & 0,00 & 2,51 & 0,00 & 0,00 & 17,45 & 25,71 & 0,00 & 0,00 & 99,76 & 49,5 & 46,7 & 3,8 \\
\hline $\begin{array}{c}11 \\
\text { GB2 }\end{array}$ & 1013 & 52,4 & 0,00 & 1,50 & 0,00 & 2,77 & 0,00 & 0,00 & 17,75 & 25,71 & 0,09 & 0,00 & 100,22 & 48,9 & 47,0 & 4,1 \\
\hline
\end{tabular}


Tabela 3 - Continuação.

\begin{tabular}{|c|c|c|c|c|c|c|c|c|c|c|c|c|c|c|c|c|}
\hline \multicolumn{2}{|c|}{ Análise } & $\mathrm{SiO}_{2}$ & $\mathrm{TiO}_{2}$ & $\mathrm{Al}_{2} \mathrm{O}_{3}$ & $\mathrm{Cr}_{2} \mathrm{O}_{3}$ & FeO & MnO & $\mathrm{NiO}$ & MgO & $\mathrm{CaO}$ & $\mathrm{Na}_{2} \mathrm{O}$ & $\mathbf{K}_{2} \mathbf{O}$ & Total & $\begin{array}{c}\% \\
\text { Wo }\end{array}$ & $\begin{array}{c}\% \\
\text { En }\end{array}$ & $\begin{array}{l}\% \\
\text { Fs }\end{array}$ \\
\hline \multicolumn{17}{|c|}{ DOMÍNIO TECTÔNICO DA FAIXA RIBEIRA } \\
\hline \multicolumn{17}{|c|}{ Metawebsterito - Fazenda da Roseta } \\
\hline $\begin{array}{c}11 \\
\text { GB2 }\end{array}$ & 1113 & 53,39 & 0,00 & 1,42 & 0,00 & 2,61 & 0,00 & 0,00 & 17,84 & 25,62 & 0,03 & 0,00 & 100,91 & 48,8 & 47,3 & 3,9 \\
\hline $\begin{array}{c}11 \\
\text { GB2 }\end{array}$ & 1513 & 51,13 & 0,00 & 1,35 & 0,00 & 2,84 & 0,00 & 0,00 & 17,76 & 25,85 & 0,07 & 0,00 & 99,00 & 49,0 & 46,8 & 4,2 \\
\hline $\begin{array}{c}11 \\
\text { GB2 }\end{array}$ & 5213 & 52,82 & 0,02 & 0,91 & 0,00 & 2,78 & 0,00 & 0,00 & 18,24 & 25,62 & 0,05 & 0,00 & 100,44 & 48,2 & 47,7 & 4,1 \\
\hline $\begin{array}{c}11 \\
\text { GB2 }\end{array}$ & 7913 & 52,61 & 0,00 & 1,34 & 0,00 & 2,66 & 0,03 & 0,00 & 17,46 & 25,3 & 0,01 & 0,00 & 99,41 & 48,9 & 47,0 & 4,1 \\
\hline $\begin{array}{c}11 \\
\text { GB3 }\end{array}$ & 8313 & 52,58 & 0,02 & 1,34 & 0,00 & 2,41 & 0,01 & 0,00 & 17,78 & 26 & 0,00 & 0,00 & 100,14 & 49,4 & 47,0 & 3,6 \\
\hline $\begin{array}{c}11 \\
\text { GB5 }\end{array}$ & 9013 & 52,58 & 0,00 & 1,24 & 0,00 & 2,6 & 0,14 & 0,00 & 17,65 & 25,47 & 0,00 & 0,00 & 99,68 & 48,9 & 47,0 & 4,1 \\
\hline $\begin{array}{c}11 \\
\text { GB6 } \\
\end{array}$ & 3413 & 52,23 & 0,00 & 1,59 & 0,00 & 2,78 & 0,00 & 0,00 & 17,45 & 25,7 & 0,00 & 0,00 & 99,75 & 49,3 & 46,6 & 4,1 \\
\hline $\begin{array}{c}11 \\
\text { GB7 }\end{array}$ & 3513 & 52,55 & 0,00 & 1,58 & 0,00 & 2,92 & 0,02 & 0,00 & 17,96 & 25,57 & 0,03 & 0,00 & 100,63 & 48,4 & 47,3 & 4,3 \\
\hline
\end{tabular}

Tabela 4 - Análises químicas representativas de espinélio.

\begin{tabular}{|c|c|c|c|c|c|c|c|c|c|c|c|c|}
\hline Análise & $\mathrm{SiO}_{2}$ & $\mathrm{TiO}_{2}$ & $\mathrm{Al}_{2} \mathrm{O}_{3}$ & $\mathrm{Cr}_{2} \mathrm{O}_{3}$ & $\mathbf{F e O}$ & $\mathrm{Fe}_{2} \mathbf{O}_{3}$ & MnO & MgO & $\mathrm{NiO}$ & $\mathrm{ZnO}$ & Total & $\begin{array}{c}\mathrm{Mg} / \\
\left(\mathrm{Mg}+\mathrm{Fe}_{2}\right)\end{array}$ \\
\hline \multicolumn{13}{|c|}{ DOMÍNIO TECTÔNICO DA FAIXA RIBEIRA } \\
\hline \multicolumn{13}{|c|}{ Metawebsterito - Fazenda da Roseta } \\
\hline 11GB259L9 & 0,13 & 0,00 & 59,95 & 3,07 & 11,43 & 5,37 & 0,15 & 18,97 & 1,07 & 0,00 & 100,14 & 75 \\
\hline 11GB260L9 & 0,18 & 0,00 & 60,39 & 3,02 & 11,85 & 4,13 & 0,07 & 18,73 & 1,00 & 0,00 & 99,19 & 74 \\
\hline 11GB264L9 & 0,11 & 0,10 & 61,72 & 2,88 & 11,66 & 3,85 & 0,05 & 19,31 & 0,92 & 0,00 & 100,61 & 72 \\
\hline FR459L2 & 0,12 & 0,06 & 45,59 & 14,05 & 20,94 & 6,57 & 0,15 & 11,43 & 0,66 & 0,00 & 99,57 & 55 \\
\hline FR462L2 & 0,05 & 0,03 & 40,52 & 17,53 & 18,38 & 9,59 & 0,22 & 12,31 & 0,77 & 0,00 & 99,4 & 54 \\
\hline SO11GB74L3 & 0,00 & 0,00 & 38,77 & 19,54 & 17,91 & 9,94 & 0,12 & 12,78 & 0,22 & 0,00 & 99,28 & 63 \\
\hline SO11GB94L3 & 0,00 & 0,10 & 39,91 & 19,53 & 16,32 & 9,10 & 0,11 & 14,03 & 0,19 & 0,00 & 99,29 & 61 \\
\hline FR448L2 & 0.00 & 0,00 & 47,22 & 13,02 & 18,97 & 6,81 & 0,15 & 12,64 & 0,78 & 0,00 & 99,66 & 54 \\
\hline \multicolumn{13}{|c|}{ Metaespinélio harzburgito - Fazenda da Roseta } \\
\hline SO11D 13L8 & 0,23 & 0,08 & 63,94 & 0,13 & 11,64 & 3,47 & 0,04 & 19,94 & 0,15 & 0,00 & 99,62 & 76 \\
\hline SO11D15L8 & 0,30 & 0,11 & 62,94 & 0,17 & 11,26 & 4,69 & 0.00 & 20,27 & 0,07 & 0,00 & 99,81 & 75 \\
\hline SO11D17L8 & 0,41 & 0,00 & 64,25 & 0,1 & 10,21 & 3,76 & 0,09 & 21,04 & 0,14 & 0,00 & 100,04 & 76 \\
\hline SO11D80L9 & 0,18 & 0,02 & 63,35 & 0,17 & 12,89 & 3,43 & 0,08 & 18,91 & 0,05 & 0,00 & 99,08 & 72 \\
\hline SO11E25L7 & 0,12 & 0,00 & 64,93 & 0,07 & 11,14 & 3,55 & 0,05 & 20,45 & 0,00 & 0,00 & 100,33 & 76 \\
\hline SO11E26L7 & 0,20 & 0,05 & 63,38 & 0,09 & 11,4 & 4,22 & 0,07 & 20,01 & 0,02 & 0,00 & 99,45 & 76 \\
\hline SO11E29L7 & 0,12 & 0,00 & 64,2 & 0,08 & 11,42 & 3,67 & 0,11 & 20,01 & 0,01 & 0,00 & 99,62 & 77 \\
\hline SO11E12L5 & 0,00 & 0,02 & 64,55 & 0.00 & 12,29 & 4,00 & 0.00 & 19,72 & 0,00 & 0,00 & 0,00 & 77 \\
\hline \multicolumn{13}{|c|}{ DOMÍNIO TECTÔNICO DA FAIXA BRASÍLIA } \\
\hline \multicolumn{13}{|c|}{ Metaespinélio ortopiroxenito - Carrancas } \\
\hline CA10B11L2 & 0,10 & 0,07 & 53,41 & 8,55 & 24,69 & 2,12 & 0,15 & 9,97 & 0,39 & 0,00 & 99,46 & 42 \\
\hline
\end{tabular}


Tabela 4 - Continuação.

\begin{tabular}{lllllllllllll} 
Análise & $\mathrm{SiO}_{2}$ & $\mathrm{TiO}_{2}$ & $\mathrm{Al}_{2} \mathrm{O}_{3}$ & $\mathrm{Cr}_{2} \mathrm{O}_{3}$ & $\mathrm{FeO}$ & $\mathrm{Fe}_{2} \mathrm{O}_{3}$ & $\mathrm{MnO}$ & $\mathrm{MgO}$ & $\mathrm{NiO}$ & $\mathrm{ZnO}$ & $\mathrm{Total}$ & $\begin{array}{c}\mathrm{Mg} / \\
\left(\mathrm{Mg}+\mathrm{Fe}_{2}\right)\end{array}$ \\
\hline
\end{tabular}

\section{DOMÍNIO TECTÔNICO DA FAIXA BRASÍLIA}

\begin{tabular}{|c|c|c|c|c|c|c|c|c|c|c|c|c|}
\hline \multicolumn{13}{|c|}{ Metaespinélio ortopiroxenito - Carrancas } \\
\hline CA10B12L2 & 0,05 & 0,06 & 53,93 & 8,51 & 24,77 & 1,79 & 0,1 & 10,01 & 0,36 & 0,00 & 99,58 & 42 \\
\hline CA10B13L2 & 0,11 & 0,07 & 53,84 & 8,16 & 24,95 & 2,46 & 0,05 & 10,04 & 0,37 & 0,00 & 100,08 & 40 \\
\hline CA10B14L2 & 0,07 & 0,00 & 53,72 & 8,18 & 25,75 & 2,98 & 0,14 & 9,49 & 0,36 & 0,00 & 100,75 & 38 \\
\hline CA10B26L2 & 0,12 & 0,00 & 55,68 & 6,11 & 24,27 & 3,09 & 0,18 & 10,66 & 0,36 & 0,00 & 100,47 & 43 \\
\hline CA10BO2L1 & 0,22 & 0,04 & 51,89 & 7,86 & 22,66 & 4,91 & 0,19 & 11,11 & 0,4 & 0,00 & 99,32 & 47 \\
\hline CA10B31L2 & 0,15 & 0,00 & 58,51 & 3,78 & 24,23 & 1,46 & 0,14 & 10,77 & 0,45 & 0,00 & 99,51 & 46 \\
\hline CA10B32L2 & 0,77 & 0,02 & 58,93 & 3,73 & 23,74 & 0,00 & 0,12 & 11,46 & 0,55 & 0,00 & 99,32 & 42 \\
\hline CA10B35L2 & 0,09 & 0,00 & 59,26 & 3,82 & 25,31 & 0,79 & 0,18 & 10,13 & 0,54 & 0,00 & 100,17 & 37 \\
\hline \multicolumn{13}{|c|}{ Metaespinélio ortopiroxenito - São Vicente de Minas } \\
\hline SV7LB & 0,03 & 0,07 & 40,09 & 23,25 & 22,0 & 2,7 & 0,23 & 10,52 & 0,1 & 0,16 & 99,8 & 46 \\
\hline SV8LB & 0,01 & 0,01 & 44,07 & 19,97 & 19,76 & 3,33 & 0,18 & 12.17 & 0,16 & 0,27 & 99,79 & 42 \\
\hline SV10LB & 0,00 & 0,02 & 58,64 & 7,2 & 15,65 & 1,75 & 0,1 & 16,42 & 0,35 & 0,18 & 100,13 & 65 \\
\hline SV20LB & 0,00 & 0,07 & 57,40 & 8,16 & 15,62 & 1,98 & 0,13 & 16,40 & 0,35 & 0,00 & 100,11 & 65 \\
\hline SV57LA & 0,01 & & 49,14 & 16,7 & 17,88 & 2,31 & 0,15 & 14,13 & 0,27 & 0,11 & 100,69 & 58 \\
\hline SV61LA & 0,02 & 0,03 & 58,23 & 6,89 & 13,61 & 2,69 & 0,08 & 17,64 & 0,43 & 0,05 & 99,67 & 70 \\
\hline SV63LA & 0,01 & 0,03 & 54,12 & 11,41 & 14,33 & 2,75 & 0,11 & 16,76 & 0,37 & 0,18 & 99,89 & 68 \\
\hline SV69LA & 0,00 & 0,01 & 59,21 & 5,73 & 13,46 & 2,44 & 0,12 & 17,60 & 0,4 & 0,20 & 0,00 & 70 \\
\hline
\end{tabular}

Tabela 5 - Análises químicas representativas de olivina.

\begin{tabular}{|c|c|c|c|c|c|c|c|c|c|c|c|c|c|c|c|}
\hline \multicolumn{2}{|c|}{ Análise } & $\mathrm{SiO}_{2}$ & $\mathrm{TiO}_{2}$ & $\mathrm{Al}_{2} \mathrm{O}_{3}$ & $\mathrm{Cr}_{2} \mathrm{O}_{3}$ & FeO & MnO & MgO & NiO & $\mathrm{CaO}$ & $\mathrm{Na}_{2} \mathrm{O}$ & $\mathbf{K}_{2} \mathbf{O}$ & $\mathrm{BaO}$ & Total & $\%$ Fo \\
\hline \multicolumn{16}{|c|}{ DOMÍNIO TECTÔNICO DA FAIXA RIBEIRA } \\
\hline \multicolumn{16}{|c|}{ Meta-harzburgito - Fazenda da Roseta } \\
\hline SO11E & $65 \mathrm{~L} 7$ & 40,81 & 0,05 & 0,00 & 0,03 & 11,84 & 0,01 & 47,11 & 0,00 & 0,02 & 0,12 & 0,00 & 0,11 & 100,1 & 87,7 \\
\hline SO11E & $73 \mathrm{~L} 7$ & 40,69 & 0,03 & 0,06 & 0,00 & 12,53 & 0,08 & 47,35 & 0,00 & 0,01 & 0,00 & 0,02 & 0,00 & 100,77 & 87,0 \\
\hline SO11E & $17 \mathrm{~L} 7$ & 39,38 & 0,00 & 0,00 & 0,00 & 12,99 & 0,00 & 47,44 & 0,32 & 0,00 & 0,00 & 0,00 & 0,00 & 100,13 & 87,7 \\
\hline SO11D & 30L11 & 41,52 & 0,05 & 0,13 & 0,00 & 12,69 & 0,15 & 44,53 & 0,05 & 0,00 & 0,02 & 0,03 & 0,00 & 99,17 & 86,2 \\
\hline SO11D & 37L11 & 41,78 & 0,05 & 0,03 & 0,00 & 12,58 & 0,07 & 44,61 & 0,00 & 0,07 & 0,00 & 0,00 & 0,19 & 99,38 & 86,3 \\
\hline \multicolumn{16}{|c|}{ Serpentinito - Fazenda da Roseta } \\
\hline FR3A & $1 \mathrm{~L} 10$ & 42,17 & & 0,03 & 0,03 & 6,2 & 0,11 & 49,87 & 0,29 & 0,04 & 0,00 & 0,03 & 0,00 & 98,77 & 93,5 \\
\hline FR3A & $4 \mathrm{~L} 10$ & 42,23 & 0,05 & 0,00 & 0,00 & 6,36 & 0,07 & 49,91 & 0,38 & 0,01 & 0,03 & 0,02 & 0,04 & 99,10 & 93,4 \\
\hline FR3A & $5 \mathrm{~L} 10$ & 41,87 & & 0,05 & 0,05 & 6,25 & 0,15 & 49,83 & 0,39 & 0,00 & 0,00 & 0,00 & 0,00 & 98,59 & 93,3 \\
\hline \multicolumn{16}{|c|}{ Metawebsterito - Fazenda da Roseta } \\
\hline FR4 & $38 \mathrm{~L} 2$ & 40,19 & 0,00 & 0,08 & 0,04 & 11,58 & 0,12 & 47,17 & 0,00 & 0,63 & 0,02 & 0,08 & 0,00 & 99,91 & 87,9 \\
\hline FR4 & $40 \mathrm{~L} 2$ & 40,36 & 0,06 & 0,04 & 0,02 & 12,49 & 0,09 & 45,87 & 0,58 & 0,05 & 0,08 & 0,01 & 0,04 & 99,69 & 86,8 \\
\hline FR4 & $47 \mathrm{~L} 2$ & 40,9 & 0,04 & 0,09 & 0,04 & 12,64 & 0,1 & 45,46 & 0,65 & 0,00 & 0,07 & 0,00 & 0,18 & 100,17 & 86,6 \\
\hline $11 \mathrm{~GB}$ & $33 \mathrm{~L} 3$ & 39,1 & 0,00 & 0,00 & 0,00 & 13,35 & 0,05 & 47,4 & 0,2 & 0,00 & 0,00 & 0,00 & 0,00 & 100,1 & 86,3 \\
\hline $11 \mathrm{~GB}$ & $40 \mathrm{~L} 3$ & 40,04 & 0,00 & 0,00 & 0,00 & 12,45 & 0,00 & 47,69 & 0,19 & 0,00 & 0,00 & 0,00 & 0,00 & 100,37 & 87,2 \\
\hline \multicolumn{16}{|c|}{ Clorita/anfibólio olivina fels - Arantina } \\
\hline AR1 & $107 \mathrm{~L} 3$ & 37,30 & 0,00 & 0,00 & 0,00 & 21,45 & 0,12 & 41,45 & 0,00 & 0,22 & 0,00 & 0,00 & 0,00 & 100,54 & 77,5 \\
\hline AR1 & 109L3 & 38,51 & 0,00 & 0,00 & 0,00 & 21,24 & 0,2 & 40,35 & 0,06 & 0,00 & 0,03 & 0,00 & 0,00 & 100,36 & 77,2 \\
\hline
\end{tabular}

continua... 
Tabela 5 - Continuação.

\begin{tabular}{|c|c|c|c|c|c|c|c|c|c|c|c|c|c|c|c|}
\hline Aná & lise & $\mathrm{SiO}_{2}$ & $\mathrm{TiO}_{2}$ & $\mathrm{Al}_{2} \mathbf{O}_{3}$ & $\mathrm{Cr}_{2} \mathrm{O}_{3}$ & FeO & MnO & MgO & $\mathrm{NiO}$ & $\mathrm{CaO}$ & $\mathrm{Na}_{2} \mathrm{O}$ & $\mathrm{K}_{2} \mathbf{O}$ & $\mathrm{BaO}$ & Total & $\%$ Fo \\
\hline \multicolumn{16}{|c|}{ DOMÍNIO TECTÔNICO DA FAIXA RIBEIRA } \\
\hline \multicolumn{16}{|c|}{ Clorita/anfibólio olivina fels - Arantina } \\
\hline AR1 & $110 \mathrm{~L} 3$ & 37,7 & 0,00 & 0,00 & 0,00 & 21,27 & 0,28 & 40,76 & 0,00 & 0,00 & 0,00 & 0,00 & 0,00 & 100,04 & 77,4 \\
\hline AR1 & 114L3 & 37,84 & 0,00 & 0,00 & 0,00 & 20,63 & 0,24 & 40,84 & 0,00 & 0,00 & 0,00 & 0,00 & 0,00 & 99,56 & 77,9 \\
\hline AR1 & 120L3 & 37,6 & 0,00 & 0,00 & 0,00 & 21,52 & 0,07 & 40,75 & 0,13 & 0,00 & 0,00 & 0,00 & 0,00 & 100,07 & 77,1 \\
\hline \multicolumn{16}{|c|}{ Metaortopiroxenitos - Serra da Garça } \\
\hline SG2B & 29L4 & 41,58 & 0,00 & 0,00 & 0,00 & 9,82 & & 49,26 & 0,3 & 0,00 & 0,00 & 0,00 & 0,00 & 100,96 & 89,9 \\
\hline SG2B & 18L4 & 41,48 & 0,07 & 0,00 & 0,00 & 9,94 & 0,05 & 48,69 & 0,19 & 0,00 & 0,00 & 0,00 & 0,00 & 100,42 & 89,7 \\
\hline SG2B & $6 \mathrm{~L} 6$ & 41,31 & 0,00 & 0,05 & 0,00 & 10,06 & 0,1 & 48,77 & 0,23 & 0,03 & 0,08 & 0,03 & 0,00 & 100,66 & 89,6 \\
\hline \multicolumn{16}{|c|}{ DOMÍNIO TECTÔNICO DA FAIXA BRASÍLIA } \\
\hline \multicolumn{16}{|c|}{ Metaespinélio-olivina ortopiroxenito - Carrancas } \\
\hline FA-IV & $27 \mathrm{~L} 10$ & 39,26 & 0,03 & 0,01 & 0,00 & 23,82 & 0,44 & 36,05 & 0,24 & 0,00 & 0,00 & 0,00 & 0,00 & 99,85 & 73,0 \\
\hline FA-IV & 29L10 & 39,09 & 0,02 & 0,04 & 0,04 & 24,26 & 0,36 & 35,32 & 0,25 & 0,03 & 0,03 & 0,00 & 0,00 & 99,44 & 72,2 \\
\hline CA10B & 17L2 & 37,64 & 0,02 & 0,04 & 0,00 & 23,06 & 0,22 & 38,2 & 0,37 & 0,01 & 0,01 & 0,02 & 0,11 & 99,7 & 74,7 \\
\hline CA10B & 19L2 & 37,86 & 0,08 & 0,07 & 0,06 & 23,5 & 0,07 & 36,82 & 0,27 & 0,02 & 0,03 & 0,00 & 0,00 & 98,78 & 73,6 \\
\hline CA10B & 24L2 & 38,4 & 0,00 & 0,00 & 0,05 & 25,75 & 0,19 & 35,23 & 0,27 & 0,00 & 0,05 & 0,00 & 0,00 & 99,94 & 71,0 \\
\hline \multicolumn{16}{|c|}{ Metaespinélio-olivina ortopiroxenito - São Vicente de Minas } \\
\hline SV3A & $105 \mathrm{~L} 11$ & 40,91 & & 0,03 & 0,04 & 15,75 & 0,24 & 42,49 & 0,39 & 0,03 & 0,05 & & & 99,89 & 82,8 \\
\hline SV3A & 94L11 & 40,05 & 0,05 & 0,06 & 0,04 & 15,53 & 0,21 & 43,64 & 0,38 & 0,04 & 0,05 & & 0,04 & 100,09 & 83,4 \\
\hline SV3A & 97L11 & 40,98 & & 0,09 & & 15,79 & 0,21 & 42,75 & 0,33 & & & & & 100,15 & 82,8 \\
\hline SV3A & $98 \mathrm{~L} 11$ & 41,3 & 0,02 & 0,03 & 0,07 & 15,64 & 0,2 & 43,12 & 0,37 & & 0,03 & & & 100,78 & 83,0 \\
\hline SV3A & 110L11 & 40,69 & & 0,05 & 0,05 & 15,97 & 0,16 & 43,19 & 0,32 & 0,02 & & & 0,19 & 100,4 & 82,9 \\
\hline \multicolumn{16}{|c|}{ Serpentinito - Fazenda Rui Barbosa - Carrancas } \\
\hline CA7B & 1L9 & 42,46 & 0,09 & 0,07 & & 4,41 & 0,38 & 52,67 & 0,28 & 0,02 & & & & 100,38 & 95,6 \\
\hline CA7B & 06L0 & 42,87 & 0,02 & 0,01 & 0,03 & 4,42 & 0,34 & 52,8 & 9,27 & 0,07 & & & & 100,81 & 95,5 \\
\hline CA7B & 11L9 & 42,78 & & 0,04 & 0,05 & 4,28 & 0,40 & 52,72 & 0,27 & 0,04 & 0,06 & & & 100,59 & 95,6 \\
\hline CA7B & 10L9 & 42,65 & & 0,07 & 0,08 & 4,22 & 0,41 & 52,62 & 0,33 & 0,01 & & 0,02 & 0,12 & 100,33 & 95,9 \\
\hline CA7B & 12L9 & 42,78 & 0,02 & & & 4,49 & 0,39 & 52,42 & 0,32 & 0,02 & 0,06 & & & 100,50 & 95,4 \\
\hline CA7B & 07L9 & 42,08 & & 0,05 & 0,07 & 4,17 & 0,39 & 52,79 & 0,27 & 0,03 & 0,08 & & & 99,86 & 95,8 \\
\hline
\end{tabular}

Tabela 6 - Análises químicas representativas de anfibólio.

\begin{tabular}{|c|c|c|c|c|c|c|c|c|c|c|c|c|c|}
\hline \multicolumn{2}{|c|}{ Análise } & $\mathrm{SiO}_{2}$ & $\mathrm{TiO}_{2}$ & $\mathrm{Al}_{2} \mathrm{O}_{3}$ & $\mathrm{Cr}_{2} \mathrm{O}_{3}$ & FeO & MnO & MgO & ZnO & $\mathrm{CaO}$ & $\mathrm{Na}_{2} \mathrm{O}$ & $\mathbf{K}_{2} \mathbf{O}$ & Total \\
\hline \multicolumn{14}{|c|}{ DOMÍNIO TECTÔNICO DA FAIXA RIBEIRA } \\
\hline \multicolumn{14}{|c|}{ Metawebsterito - Fazenda da Roseta } \\
\hline FR4 & $37 \mathrm{~L} 2$ & 51,77 & 0,10 & 6,69 & 0,43 & 3,51 & 0,00 & 19,38 & 0,18 & 14,06 & 0,23 & 0,10 & 96,45 \\
\hline FR4 & $60 \mathrm{~L} 2$ & 51,90 & 0,13 & 5,83 & 0,28 & 3,22 & 0,05 & 20,70 & 0,16 & 13,85 & 0,24 & 0,09 & 96,45 \\
\hline FR4 & $67 \mathrm{~L} 2$ & 52,45 & 0,00 & 6,18 & 0,31 & 3,74 & 0,00 & 19,54 & 0,10 & 14,02 & 0,28 & 0,08 & 96,70 \\
\hline SO11GB & $30 \mathrm{~L} 3$ & 51,40 & 0,17 & 6,98 & 0,09 & 4,08 & 0,00 & 20,54 & 0,00 & 13,57 & 0,43 & 0,17 & 97,43 \\
\hline SO11GB & $84 \mathrm{~L} 3$ & 52,98 & 0,00 & 6,34 & 0,00 & 4,04 & 0,00 & 21,19 & 0,00 & 13,67 & 0,37 & 0,08 & 98,67 \\
\hline SO11GB2 & 19L9 & 52,62 & 0,12 & 6,91 & 0,35 & 3,71 & 0,01 & 20,23 & 0,12 & 13,53 & 0,45 & 0,16 & 98,21 \\
\hline SO11GB2 & 20L9 & 52,70 & 0,07 & 7,04 & 0,35 & 3,92 & 0,07 & 19,95 & 0,22 & 12,65 & 0,45 & 0,09 & 97,51 \\
\hline SO11GB2 & 25L9 & 52,23 & 0,15 & 8,59 & 0,13 & 4,35 & 0,09 & 19,64 & 0,14 & 12,73 & 0,60 & 0,21 & 98,86 \\
\hline
\end{tabular}


Tabela 6 - Continuação.

\begin{tabular}{|c|c|c|c|c|c|c|c|c|c|c|c|c|c|}
\hline \multicolumn{2}{|c|}{ Análise } & $\mathrm{SiO}_{2}$ & $\mathrm{TiO}_{2}$ & $\mathrm{Al}_{2} \mathrm{O}_{3}$ & $\mathrm{Cr}_{2} \mathrm{O}_{3}$ & FeO & MnO & MgO & $\mathrm{ZnO}$ & $\mathrm{CaO}$ & $\mathrm{Na}_{2} \mathrm{O}$ & $\mathbf{K}_{2} \mathbf{O}$ & Total \\
\hline \multicolumn{14}{|c|}{ DOMÍNIO TECTÔNICO DA FAIXA RIBEIRA } \\
\hline \multicolumn{14}{|c|}{ Serpentinito - Fazenda da Roseta } \\
\hline FR-3A & 7L10 & 57,81 & 0,00 & 1,33 & 0,14 & 1,58 & 0,12 & 21,81 & 0,12 & 13,58 & 0,02 & 0,01 & 96,52 \\
\hline FR-3A & $8 \mathrm{~L} 10$ & 58,30 & 0,03 & 1,60 & 0,12 & 1,78 & 0,02 & 21,69 & 0,13 & 13,20 & 0,04 & 0,00 & 96,91 \\
\hline \multicolumn{14}{|c|}{ Ortopiroxenito - Serra da Garça } \\
\hline SG2B & 7L4 & 59,90 & 0,00 & 0,00 & 0,00 & 7,34 & 0,06 & 30,54 & 0,00 & 0,21 & 0,00 & 0,00 & 98,05 \\
\hline \multicolumn{14}{|c|}{ Clorita/anfibólio olivina fels - Arantina } \\
\hline AR1121L3 & 53,90 & 0,00 & 0,42 & 0,00 & 3,47 & 0,03 & 23,74 & 0,00 & 13,23 & 0,16 & 0,00 & 94,95 & \\
\hline \multicolumn{14}{|c|}{ DOMÍNIO TECTÔNICO DA FAIXA BRASÍLIA } \\
\hline \multicolumn{14}{|c|}{ Metaespinélio ortopiroxenito - Carrancas } \\
\hline CA10B & 1L1 & 47,35 & 0,40 & 10,08 & 0,24 & 6,15 & 0,01 & 19,49 & 0,03 & 13,50 & 0,82 & 0,00 & 98,07 \\
\hline CA10B & 33L2 & 48,99 & 0,42 & 10,26 & 0,11 & 6,94 & 0,04 & 16,58 & 0,09 & 13,63 & 0,93 & 0,18 & 98,17 \\
\hline CA10B & $8 \mathrm{~L} 1$ & 46,42 & 0,48 & 10,86 & 0,20 & 7,48 & 0,16 & 18,65 & 0,03 & 12,61 & 0,87 & 0,20 & 97,96 \\
\hline CA10B & 9L1 & 48,51 & 0,50 & 10,33 & 0,10 & 7,24 & 0,05 & 17,14 & 0,08 & 12,71 & 0,93 & 0,18 & 97,77 \\
\hline FA-IV & 25L10 & 51,41 & 0,40 & 7,81 & 0,09 & 6,47 & 0,15 & 17,76 & 0,12 & 12,29 & 1,01 & 0,12 & 97,63 \\
\hline FA-IV & 32L10 & 51,14 & 0,42 & 7,49 & 0,19 & 6,32 & 0,07 & 17,85 & 0,12 & 12,37 & 0,84 & 0,11 & 96,92 \\
\hline FA-IV & $35 \mathrm{~L} 10$ & 51,02 & 0,47 & 7,71 & 0,14 & 5,87 & 0,12 & 18,03 & 0,14 & 13,73 & 0,99 & 0,15 & 98,37 \\
\hline FA-IV & 56L10 & 53,06 & 0,47 & 6,53 & 0,29 & 5,55 & 0,07 & 18,72 & 0,14 & 12,53 & 0,77 & 0,08 & 98,21 \\
\hline \multicolumn{14}{|c|}{ Metaespinélio-olivina ortopiroxenito - Carrancas } \\
\hline SV3A & 102L11 & 53,22 & 0,38 & 6,94 & 0,25 & 3,43 & 0,03 & 19,43 & 0,08 & 12,85 & 0,57 & 0,17 & 97,35 \\
\hline SV3A & 106L11 & 53,07 & 0,22 & 6,85 & 0,15 & 3,49 & 0,02 & 18,68 & 0,03 & 12,71 & 0,52 & 0,14 & 95,88 \\
\hline SV3A & $85 \mathrm{~L} 11$ & 52,50 & 0,42 & 6,46 & 0,27 & 3,38 & 0,02 & 19,47 & 0,12 & 12,56 & 0,53 & 0,14 & 95,87 \\
\hline SV3A & 90L11 & 52,36 & 0,40 & 7,21 & 0,19 & 3,34 & 0,13 & 19,01 & 0,12 & 12,10 & 0,62 & 0,20 & 95,68 \\
\hline SV3A & 91L11 & 51,77 & 0,53 & 7,02 & 0,24 & 3,66 & 0,12 & 19,75 & 0,04 & 12,31 & 0,64 & 0,15 & 96,23 \\
\hline SV3A & 92L11 & 52,64 & 0,20 & 6,64 & 0,09 & 3,45 & 0,10 & 19,99 & 0,17 & 12,51 & 0,55 & 0,14 & 96,48 \\
\hline SV3A & 102L11 & 53,22 & 0,38 & 6,94 & 0,25 & 3,43 & 0,03 & 19,43 & 0,08 & 12,85 & 0,57 & 0,17 & 97,35 \\
\hline SV3A & 106L11 & 53,07 & 0,22 & 6,85 & 0,15 & 3,49 & 0,02 & 18,68 & 0,03 & 12,71 & 0,52 & 0,14 & 95,88 \\
\hline SV3A & 102L11 & 53,22 & 0,38 & 6,94 & 0,25 & 3,43 & 0,03 & 19,43 & 0,08 & 12,85 & 0,57 & 0,17 & 97,35 \\
\hline
\end{tabular}

estão ilustradas as composições de trezentas análises pontuais. No domínio da Faixa Ribeira, ortopiroxênio sem deformação de metawebsterito e meta-harzburgito apresenta núcleo enstatítico que grada para bordas bronzíticas. Nos cristais deformados, o padrão de distribuição é irregular, não apenas em termos de enstatita, mas também de $\mathrm{Al}_{2} \mathrm{O}_{3}$. No diagrama En versus $\mathrm{Al}_{2} \mathrm{O}_{3}$ (Fig. 9) é possível observar a variação da porcentagem de $\mathrm{Al}_{2} \mathrm{O}_{3}$ no conjunto de ortopiroxênio de ambos os domínios. O diagrama demonstra haver ampla variação no conteúdo de alumina em metawebsteritos com maior grau de deformação e uma relativa homogeneidade em amostras com textura poligonizada. O diagrama também exibe uma linha, definida por Dick (1977), representativa da tendência geral de composição de grãos de ortopiroxênio submetidos a condições de equilíbrio variando de baixa a alta temperatura. Desta forma, conclui-se que a ampla variação composicional do ortopiroxênio no domínio da Faixa Ribeira resulta de condições de desequilíbrios ao longo do metamorfismo, com a deformação atuando na redistribuição da alumina, de forma semelhante à descrita por Obata (1980) em peridotitos deformados de Ronda.

Como visto anteriormente, clinopiroxênio ocorre apenas em rochas do domínio Ribeira. Nestas rochas, tanto neoblastos poligonizados quanto grãos poiquiloblástico, com ortopiroxênio e anfibólio inclusos são relativamente homogêneos, com composição no campo do diopsídio (Fig. 8).

No domínio Ribeira, espinélio em metawebsteritos apresenta composição de ceylonita de acordo com Tröger (1979) e Deer et al. (1992). No meta-harzburgito 

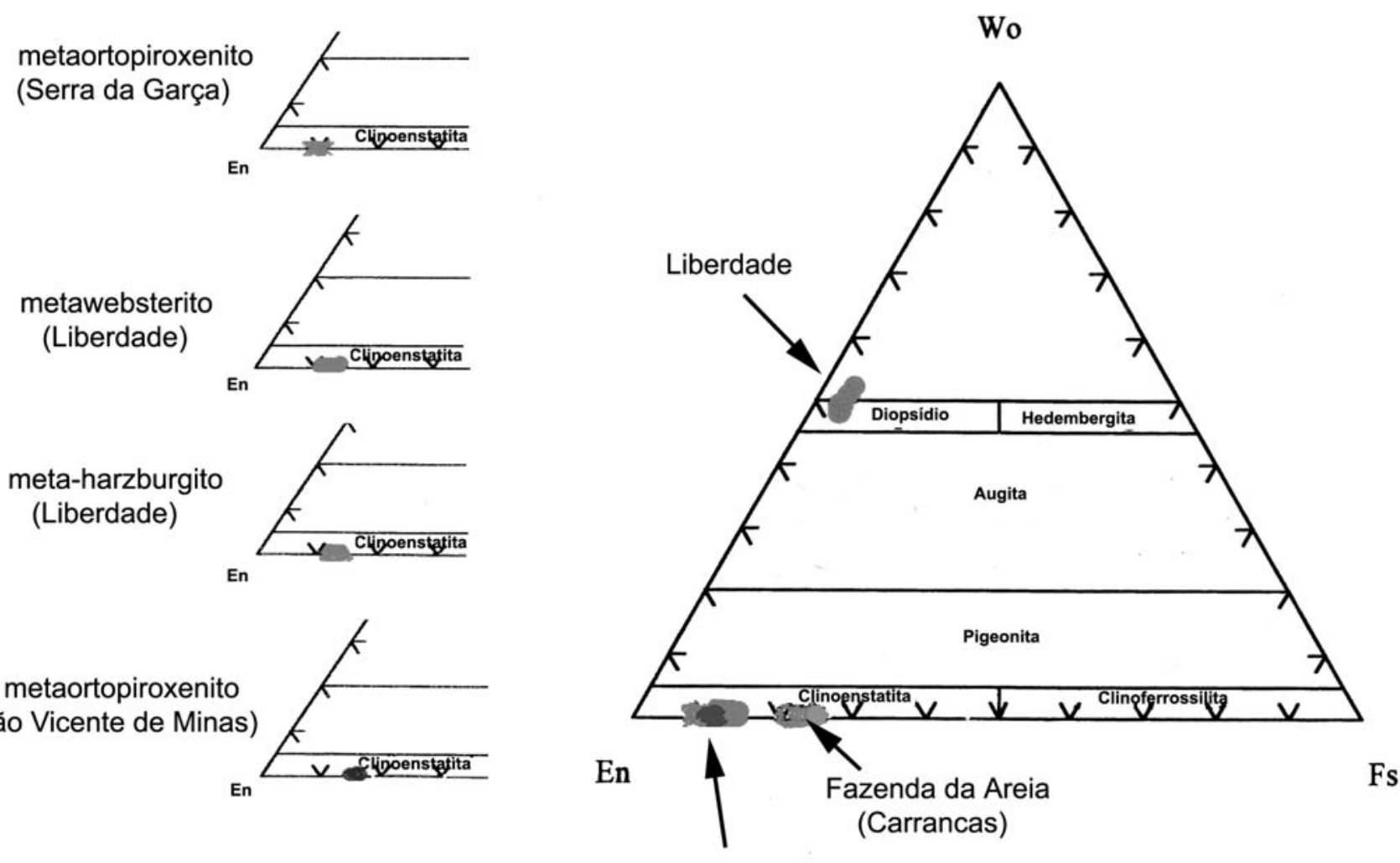

Demais corpos ultramáficos

Figura 8 - Diagrama En-Wo-Fs (Podervaart \& Hess 1951) para os piroxênios analisados. À esquerda, composições de rochas cujos pontos estão sobrepostos no diagrama.

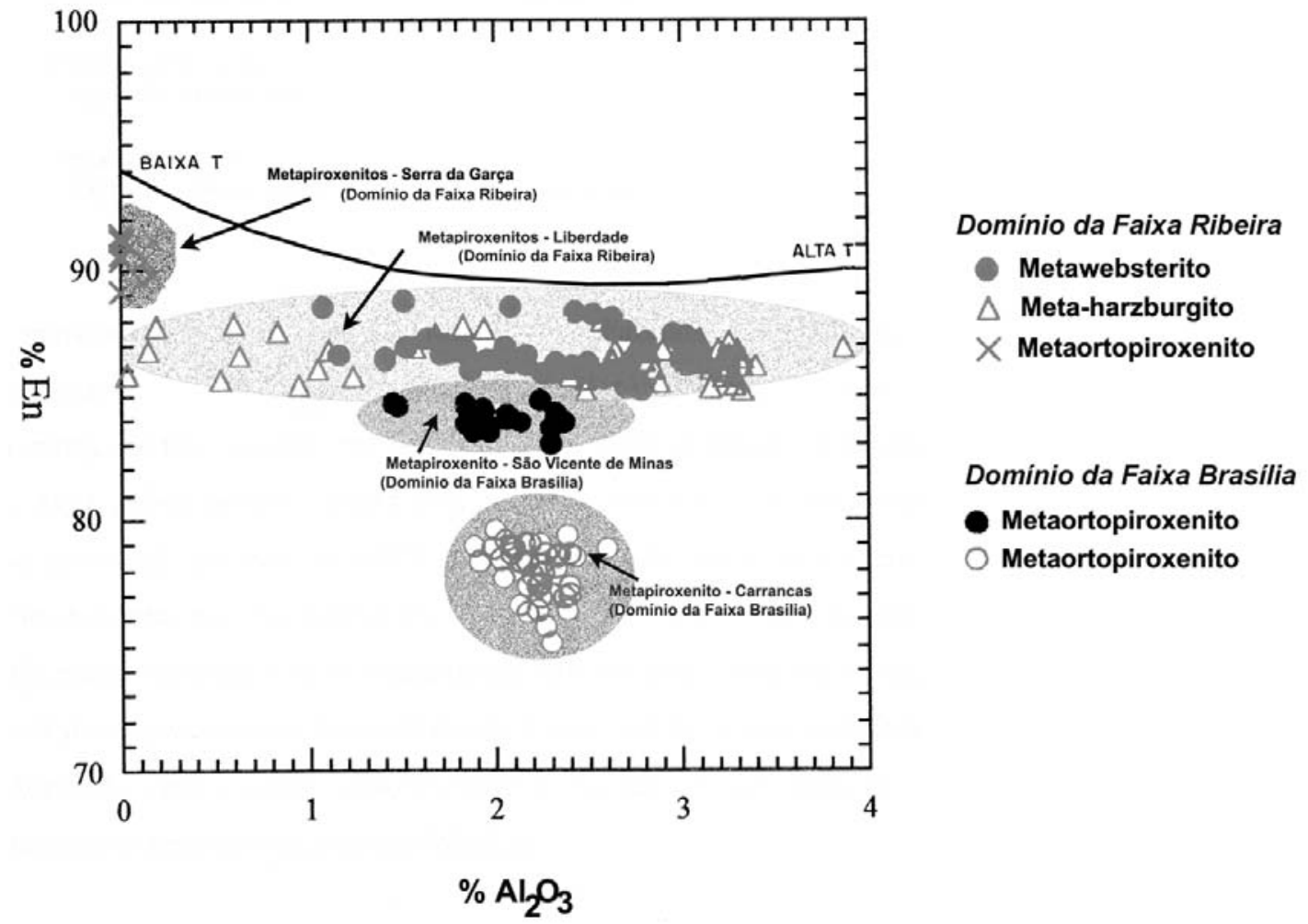

Figura 9 - Diagrama exibindo variação da porcentagem de Enstatita em relação à porcentagem de $\mathrm{Al}_{2} \mathrm{O}_{3}$ para ortopiroxênios de ambos os domínios. 
constitui espinélio sensu strictu, com baixo conteúdo de $\mathrm{Cr}_{2} \mathrm{O}_{3}$. No domínio tectônico da Faixa Brasília, o espinélio dos corpos piroxeníticos de São Vicente de Minas e de Carrancas é pleonasto.

A figura 10 ilustra variações de $\mathrm{Cr} / \mathrm{Cr}+\mathrm{Al}$ versus $\mathrm{Mg} / \mathrm{Mg}+\mathrm{Fe}^{2+}$ para o conjunto de grãos de espinélio. A relação entre estas razões passou a ser comum em estudos envolvendo espinélio desde que Irvine (1967) demonstrou que altas razões $\mathrm{Cr} / \mathrm{Cr}+\mathrm{Al}(>50 \%)$, seriam compatíveis com geração do mineral a partir de fusões ígneas, em contraste com espinélios oriundo de rochas alpinas que apresentam ampla variação na razão $\mathrm{Cr} /$ $\mathrm{Al}$ e um intervalo restrito de $\mathrm{Mg} / \mathrm{Fe}^{2+}$. Trabalhos posteriores demonstraram, contudo, que esta razão, embora ineficaz como indicador petrogenético nos moldes definidos por Irvine, podem refletir variações da composição ao longo de processos metamórficos (Evans \& Frost 1975, Dick \& Bullen 1984, Sack \& Ghiorso 1991, Haggerty 1991). Os resultados das amostras aqui analisadas demonstram que em ambas as regiões os grãos de espinélio apresentam razões compatíveis com produtos de metamorfismo regional. No harzburgito, espinélio simplectítico apresenta composições compatíveis com as bordas dos cristais granulares que, por sua vez, exibem aumento de $\mathrm{MgO} / \mathrm{FeO}$ em direção aos núcleos.

Nas rochas provenientes do domínio da Faixa Ribeira, o conteúdo de forsterita em olivina varia entre $\mathrm{Fo}_{77}$ e $\mathrm{Fo}_{93,5}$ e, no domínio tectônico da Faixa Brasília, entre $\mathrm{Fo}_{71} \mathrm{a} \mathrm{Fo}_{96}$. As variações da porcentagem de forsterita são restritas entre grãos de uma mesma rocha, que se apresentam relativamente homogêneos. As diferenças mais relevantes ocorrem entre olivinas de litotipos distintos, refletindo a composição global (i.e. olivina de meta-harzburgito versus olivina de metawebsterito).

A análise textural revela que tais variações não estão associadas a um padrão de zoneamento núcleo-borda, mas refletem difusão de Mg na olivina durante a formação de espinélio metamórfico. Para todas as rochas analisadas, o teor de $\mathrm{Ni}$ da olivina independe do conteúdo de Fo (Fig. 11).

Para a maioria das amostras, a porcentagem de $\mathrm{NiO}$ é superior a porcentagem de $\mathrm{MnO}$, compondo razões de $\mathrm{NiO} / \mathrm{MnO}$ compatíveis com formação primária a partir de fusões ígneas, onde o $\mathrm{Kd}_{\mathrm{Ni}}$ é superior ao $\mathrm{Kd}_{\mathrm{Mn}}$. São exceções as amostras de Arantina e da Fazenda Rui Barbosa, onde $\mathrm{NiO}<\mathrm{MnO}$, com razões compatíveis com olivina gerada por metamorfismo progressivo (Evans 1977). Além de apresentar alta razão $\mathrm{Mg} / \mathrm{Mg}+\mathrm{Fe}$ associada a baixo $\mathrm{NiO}$ e alto $\mathrm{MnO}$, a olivina da Fazenda Rui Barbosa e de Arantina também não apresentam o enriquecimento de $\mathrm{NiO}$ em direção as bordas, que é padrão em todas as demais rochas analisadas. Tal comportamento é observado em olivina gerada por metamorfismo de serpentinito (Vance \&

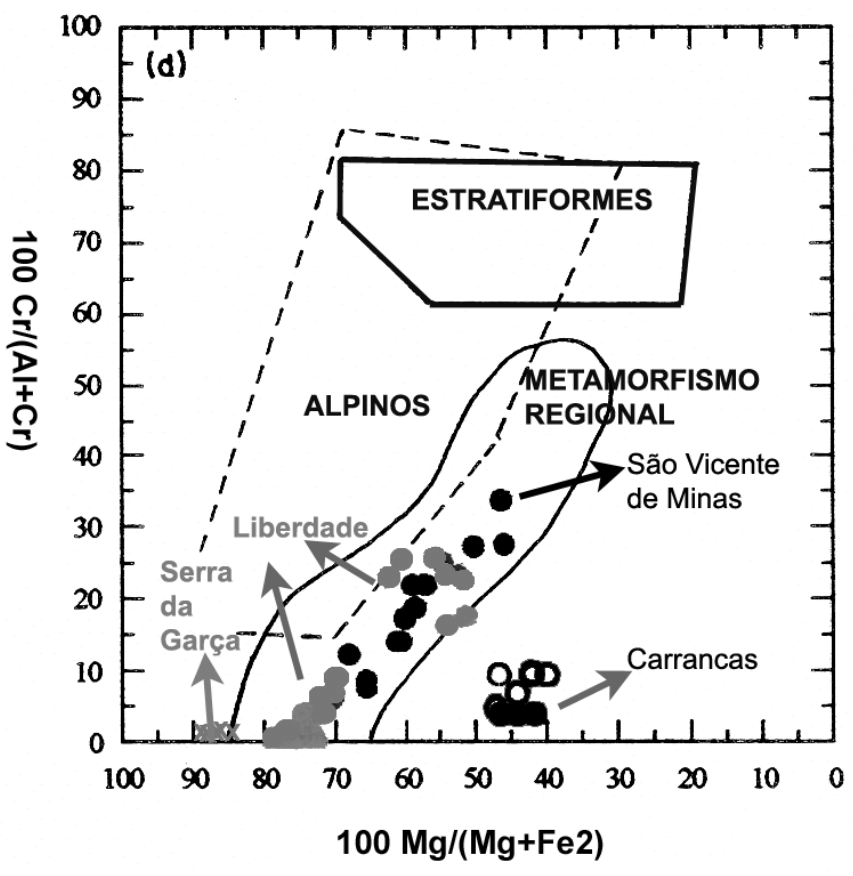

Figura 10 - Diagrama $\mathrm{Cr} / \mathrm{Cr}+\mathrm{Al}$ versus $\mathrm{Mg} / \mathrm{Mg}+\mathrm{Fe}^{2+}$ para espinélio de ambos os domínios confrontados com campos de concentração de espinélio de diferentes procedências (vide texto para referências). Em preto espinélio do domínio tectônico da Faixa Brasília; em cinza espinélio do domínio da Faixa Ribeira.

Dungan 1977). Os dados indicam, portanto, uma formação essencialmente metamórfica para a formação de olivina na Fazenda Rui Barbosa e em Arantina.

Segundo nomenclatura de Leake (1978), os anfibólios do domínio da Faixa Ribeira são hornblenda tremolítica a Mg-hornblenda para os metawebsterito e espinélio hornblendito; tremolita para os serpentinitos e clorita/anfibólio-olivina fels; e antofilita magnesiana para os ortopiroxenitos. No domínio tectônico da Faixa Brasília, tem-se: hornblenda actinolítica a hornblenda magnesiana entre os metaortopiroxenitos de Carrancas e hornblenda tremolítica em São Vicente de Minas.

\section{DISCUSSÃO}

Reações de equilíbrio das associações de alto grau Este grupo inclui as rochas com evidências texturais (ou químicas) de crescimento metamórfico de piroxênios e olivina, passíveis de serem representadas nos sistemas $\mathrm{CaO}-\mathrm{MgO}-\mathrm{Al}_{2} \mathrm{O}_{3}-\mathrm{SiO}_{2}-\mathrm{H}_{2} \mathrm{O}(\mathrm{CMASH})$ e $\mathrm{MgO}-$ $-\mathrm{Al}_{2} \mathrm{O}_{3}-\mathrm{SiO}_{2}-\mathrm{H}_{2} \mathrm{O}(\mathrm{MASH})$.

\section{ZONA DO DOMÍNIO TECTÔNICO DA FAIXA RIBEIRA} Sistema CMASH Nos metawebsteritos, constata-se que o limite termal do par anfibólio-olivina foi atingido 


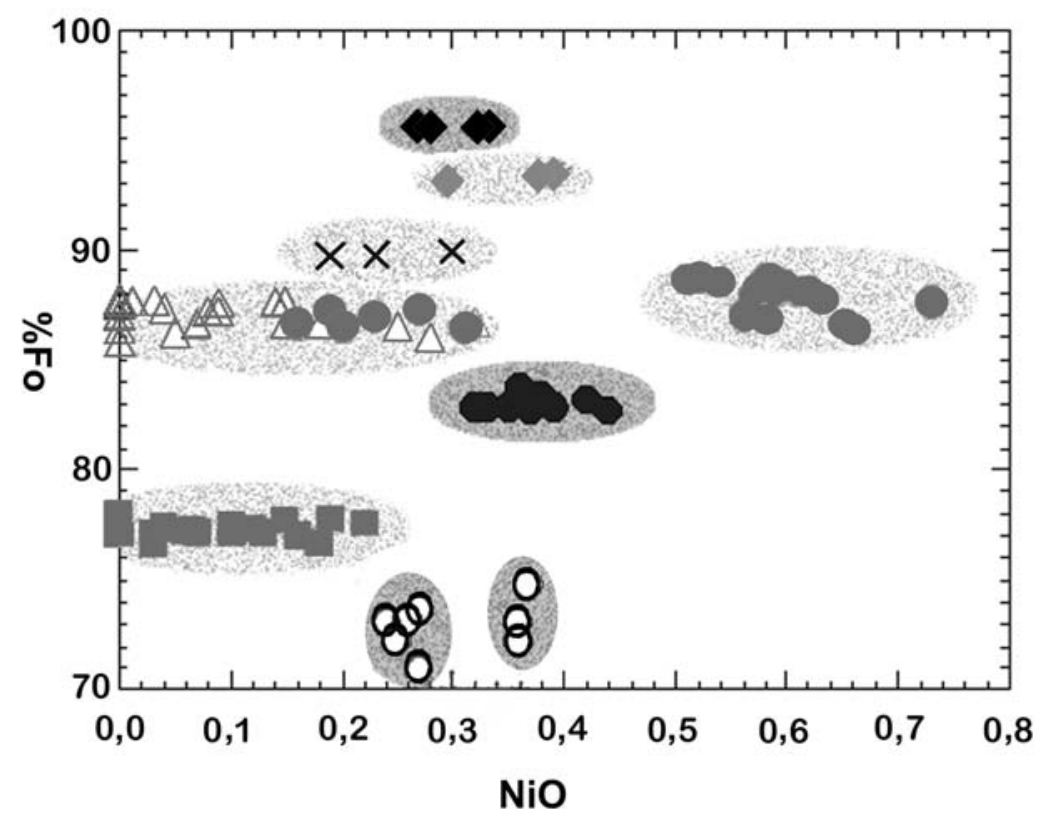

Domínio da Faixa Ribeira

Metawebsterito

Meta-harzburgito

Metaortopiroxenito

Olivina-tremolita/clorita fels

Serpentinito

\section{Domínio da Faixa Brasilia}

- Metaortopiroxenito

O Metaortopiroxenito

Serpentinito

Figura 11 - Diagrama exibindo variação da porcentagem de Forsterita em relação à porcentagem de NiO para olivinas de ambos os domínios.

com geração simultânea de orto- e clinopiroxênio deformados, por meio de reações passíveis de ocorrerem em torno de $810 \pm 30^{\circ} \mathrm{C}$ (Bücher \& Frey 2002), segundo as equações (4) e (5):

$$
\begin{aligned}
& \underset{\text { Cre }}{\mathrm{Ca}_{2} \mathrm{Mg}_{5} \mathrm{Si}_{8} \mathrm{O}_{22}(\mathrm{OH})_{2}}+\underset{\text { Fo }}{\mathrm{Mg}_{2} \mathrm{SiO}_{4}=} \\
& =\underset{\mathrm{En}}{2,5 \mathrm{Mg}_{2} \mathrm{Si}_{2} \mathrm{O}_{6}}+\underset{\mathrm{Di}}{2 \mathrm{CaMgSi}_{2} \mathrm{O}_{6}}+\mathrm{H}_{2} \mathrm{O}
\end{aligned}
$$$$
\mathrm{Ca}_{2}\left(\mathrm{Mg}_{3}, \mathrm{Al}_{2}\right)\left(\mathrm{Si}_{6} \mathrm{Al}_{2}\right) \mathrm{O}_{22}(\mathrm{OH})_{2}+3 \mathrm{Mg}_{2} \mathrm{SiO}_{4}=
$$$$
\text { Al-anf }
$$$$
\text { Fo }
$$

$$
=\underset{\mathrm{En}}{2,5 \mathrm{Mg}_{2} \mathrm{Si}_{2} \mathrm{O}_{6}}+\underset{\mathrm{Sp}}{2 \mathrm{MgAl}_{2} \mathrm{O}_{4}}+\underset{\mathrm{Di}}{2 \mathrm{CaMgSi}_{2} \mathrm{O}_{6}}+\mathrm{H}_{2} \mathrm{O}
$$

Pares adjacentes de clino- e ortopiroxênio deformados exibiram resultados incoerentes, gerando equações indefinidas para o termômetro de Wells (1977), indicando desequilíbrio entre as fases. A utilização de cristais indeformados forneceu temperaturas em torno de $800^{\circ} \mathrm{C}$. O geotermômetro de Sack \& Ghiorso (1991) também não se mostrou aplicável a estas rochas, indicando, da mesma forma, condições de desequilíbrio para o par olivina-espinélio.

A ausência de plagioclásio, nestas rochas, permite definir os limites inferiores de pressão dos sistemas em torno de 5 kbar (Bucher \& Frey 2002), de acordo com a equação (6):

$$
\begin{aligned}
& \underset{\text { Tre }}{2 \mathrm{Ca}_{2} \mathrm{Mg}_{5} \mathrm{Si}_{8} \mathrm{O}_{22}(\mathrm{OH})_{2}}+\underset{\mathrm{Sp}}{4 \mathrm{MgAl}_{2} \mathrm{O}_{4}}= \\
& =6 \mathrm{Mg}_{2} \mathrm{SiO}_{4}+\mathrm{Mg}_{2} \mathrm{Si}_{2} \mathrm{O}_{6}+4 \mathrm{CaAl}_{2} \mathrm{Si}_{2} \mathrm{O}_{8}+2 \mathrm{H}_{2} \mathrm{O} \\
& \mathrm{Fo} \quad \mathrm{En} \text { Anor }
\end{aligned}
$$

Sistema MASH Nos espinélios meta-harzburgitos, a presença de espinélio associado à ortopiroxênio e olivina, define limites de pressão entre 8 e 20 kbar (O'Hara 1967, Green \& Ringwood 1970), fora dos quais a fase aluminosa seria representada, respectivamente, por plagioclásio e granada. A expulsão da alumina da estrutura do ortopiroxênio e consequente formação de espinélio, por queda de temperatura, é evidenciada nestas rochas por textura simplectítica envolvendo espinélio, ortopiroxênio e olivina. Esta relação é expressa pelo equilíbrio (MacGregor 1974, Obata 1976):

$$
\begin{gathered}
\underset{\mathrm{Al}-\mathrm{En}}{\mathrm{MgSiO}} \cdot \mathrm{Al}_{2} \mathrm{O}_{3}+x \mathrm{Mg}_{2} \mathrm{SiO}_{4}= \\
\mathrm{Ol} \\
=\underset{\mathrm{Sp}}{\mathrm{MgAl}_{2} \mathrm{O}_{4}}+(1+x) \mathrm{MgSiO}_{3} \\
\mathrm{En}
\end{gathered}
$$

onde o valor de $x$ reflete as condições físicas do sistema.

Para as rochas aqui estudadas, as curvas de equilíbrio de Berman (1991) para esta reação indicam temperaturas variando entre 400 e $550^{\circ} \mathrm{C}$, em 
associações com espinélios simplectíticos, e entre 550 e $750^{\circ} \mathrm{C}$, em associações com espinélios granulares. $\mathrm{O}$ geotermômetro de Gasparik \& Newton (1984), aplicado às mesmas associações fornecem temperaturas em torno de $820^{\circ} \mathrm{C}$ para espinélios granulares e, em torno de $560^{\circ} \mathrm{C}$ para espinélios que ocorre em intercrescimentos simplectíticos. Ambos os resultados corroboram a hipótese de resfriamento, com queda de temperatura determinando o limite da solução sólida de Al no ortopiroxênio. Neste processo, os primeiros cristais gerados assumem formas compactas resultante de crescimento contínuo e, os mais tardios, hábito vermicular e composição química compatível com a borda dos cristais granulares.

Deve-se observar que, nas condições onde espinélio é estável, a adição de $\mathrm{H}_{2} \mathrm{O}$ à associação olivina+espinélio+ortopiroxênio resulta em formação de Mg-clorita e, assim, a presença de clorita poiquiloblástica em algumas amostras de harzburgito sugere hidratação localizada, segundo a reação que define o limite máximo de ocorrência deste mineral no sistema MASH, segundo a reação (O'Hara 1967, Evans 1977):

$$
\begin{aligned}
& \underset{\mathrm{En}}{\mathrm{Mg}_{2} \mathrm{Si}_{2} \mathrm{O}_{6}}+\underset{\mathrm{Fo}}{\mathrm{Mg}_{2} \mathrm{SiO}_{4}}+\underset{\mathrm{Sp}}{\mathrm{MgAl}_{2} \mathrm{O}_{4}}+\mathrm{H}_{2} \mathrm{O}= \\
& =\underset{\mathrm{Cl}}{\left(\mathrm{Mg}_{6-\mathrm{x}} \mathrm{Al}_{\mathrm{x}}\right)\left(\mathrm{Si}_{4-\mathrm{x}} \mathrm{Al}_{\mathrm{x}}\right) \mathrm{O}_{10}(\mathrm{OH})_{8}}
\end{aligned}
$$

Sendo o teor de alumina da clorita crescente com o aumento de temperatura (Jenkins \& Chernosky 1986), esta reação define um geotermômetro que, quando aplicado às rochas aqui estudadas fornece temperaturas próximas de $600^{\circ} \mathrm{C}$ (database de Berman 1991).

Assim como entre as rochas websteríticas, o geotermômetro de Sack \& Ghiorso (1991) resultou em equações indefinidas para os espinélio meta-harzburgitos, indicando condições de desequilibro químico.

\section{DOMÍNIO TECTÔNICO DA FAIXA BRASÍLIA}

Sistema CMASH O metamorfismo progressivo em espinélio-olivina metaortopiroxenitos do domínio tectônico da Faixa Brasília não atinge o campo de estabilidade de clinopiroxênio, mineral ausente nas rochas estudadas do domínio tectônico da Faixa Brasília, onde hornblenda+espinélio representam as fases ricas em $\mathrm{Ca}$ e Al. Este é caracterizado por blastese de ortopiroxênio e olivina, para a qual é fornecida a seguinte reação (Berman 1991):

$$
\underset{\text { Tre }}{2 \mathrm{Ca}_{2} \mathrm{Mg}_{5} \mathrm{Si}_{8} \mathrm{O}_{22}(\mathrm{OH})_{2}}+\underset{\mathrm{Sp}}{4 \mathrm{MgAl}_{2} \mathrm{O}_{4}}=
$$

$$
2 \mathrm{Mg}_{2} \mathrm{SiO}_{4}+5 \mathrm{Mg}_{2} \mathrm{Si}_{2} \mathrm{O}_{6}+4 \mathrm{CaAl}_{2} \mathrm{SiO}_{2}+2 \mathrm{H}_{2} \mathrm{O}\left(+16 \mathrm{O}^{-}\right)
$$

A homogeneidade química das fases minerais presentes nestas rochas indica eficiência do reequilíbrio a que foram submetidas. Condições de equilíbrio são também indicadas pelo geotermômetro de Sack e Ghiorso (1991), que fornecem temperaturas em torno de $500^{\circ} \mathrm{C}$ para piroxenitos da Fazenda da Areia (Carrancas) e de $550^{\circ} \mathrm{C}$ para piroxenitos de São Vicente de Minas.

Para a associação clorita+espinélio+olivina + ortopiroxênio, as curvas do equilíbrio $\mathrm{En}+\mathrm{Sp}+\mathrm{Fo}+\mathrm{H}_{2} \mathrm{O}$ $=\mathrm{Cl}$ fornecem temperaturas variando entre $580 \mathrm{a} 640^{\circ} \mathrm{C}$ para piroxenitos da Fazenda da Areia e de São Vicente de Minas, respectivamente.

\section{Reações de equilíbrio para as rochas com talco e/ou antofilita (sistema MSH) DOMÍNIO TECTÔNICO DA FAIXA RIBEIRA No} sistema $\mathrm{MgO}-\mathrm{SiO}_{2}-\mathrm{H}_{2} \mathrm{O}$, a formação de antofilita decorre de processos intermediários da transformação talco-piroxênio:

$\mathrm{Ta}+\mathrm{Fo}=\mathrm{En}+\mathrm{H}_{2} \mathrm{O}$

$\mathrm{Ta}=\mathrm{En}+\mathrm{H}_{2} \mathrm{O}+\mathrm{SiO}_{2}$

Associações contendo antofilita se desenvolvem sob intervalos restritos de temperatura e sob condições de pressão máxima de $10 \mathrm{~kb}$. O campo de coexistência de olivina e antofilita é limitado pelas reações 12 e 13. As reações 14 e 15 definem o campo de coexistência de antofilita e quartzo (Greenwwod 1963, 1971, Chernosky et al.1985, Bucher \& Frey 2002):

$\mathrm{Tc}+\mathrm{Fo}=\mathrm{Ant}+\mathrm{H}_{2} \mathrm{O}$

$\mathrm{Ant}+\mathrm{Fo}=\mathrm{En}+\mathrm{H}_{2} \mathrm{O}$

$\mathrm{Tc}=\mathrm{Ant}+\mathrm{H}_{2} \mathrm{O}+\mathrm{SiO}_{2}$

$\mathrm{En}+\mathrm{H}_{2} \mathrm{O}+\mathrm{SiO}_{2}=$ Ant

Desta forma as rochas maciças constituídas por antofilita que substitui ortopiroxênio, na região da Serra da Garça, registram um intervalo de temperatura entre 650 e $800^{\circ} \mathrm{C}$, atingido durante o metamorfismo retrogressivo. A hipótese de crescimento concomitante de ortopiroxênio e clorita sob grau metamórfico superior, nestas rochas, é justificada pelo baixo conteúdo de $\mathrm{Al}_{2} \mathrm{O}_{3}$ da enstatita e pelas texturas de intercrescimento entre estes minerais descritas por Almeida (1998). Tal formação "precoce" de enstatita no campo da clorita desenvolve-se em sistemas pobres em cálcio (Greenwood 1963, 1971, Smith \& Riter 1997). Demais cloritas, com características texturais diversas, teriam seu desenvolvimento ao longo do caminho retrogressivo. 
DOMÍNIO TECTÔNICO DA FAIXA BRASÍLIA No domínio tectônico da Faixa Brasília, a presença de talco em ocorrências isoladas ou como auréolas não xistosas entre os corpos e suas encaixantes, indica uma origem por transferência metassomática resultante de reações entre as rochas ultramáficas e suas encaixantes silicosas sob regime de metamorfismo progressivo, sob temperaturas médias em torno de $300^{\circ} \mathrm{C}$, passível de atingir $500^{\circ} \mathrm{C}$ em presença de $\mathrm{CO}_{2}$ (Greenwod 1963, 1971, Chernosky et al.1985):

$$
\begin{aligned}
& 2 \mathrm{Serp}+2 \mathrm{SiO}_{2}=\mathrm{Tc}+\mathrm{H}_{2} \mathrm{O} \\
& \mathrm{Serp}+3 \mathrm{CO}_{2}=\mathrm{Tc}+3 \mathrm{MgS}+3 \mathrm{H}_{2} \mathrm{O}
\end{aligned}
$$

\section{Reações de equilíbrio para os serpentinitos No} domínio Ribeira, as relações texturais indicam ser os serpentinitos estudados resultantes da hidratação de protólitos granulares contendo olivina e piroxênios, processo este passível de ocorrer em amplo intervalo de temperatura: 350 a aproximadamente $650^{\circ} \mathrm{C}$ (Johannes 1969, Evans 1977). No domínio da Faixa Brasília, a ausência de cristais relictos ou textura mesh, não permitem reconhecer características da textura original. Em um dos corpos analisados (Fazenda Rui Barbosa), a blastese de olivina em serpentinitos indica que condições mínimas para a formação deste mineral foram atingidas $\left(=400^{\circ} \mathrm{C}\right.$; Evans 1977$)$, ao longo de metamorfismo progressivo. Deve-se observar que, de forma diferente das rochas da Faixa Brasília, a blastese de olivina+tremolita em clorita/anfibólio olivina fels nas rochas de Arantina, no domínio da Faixa Ribeira, está associada a um metamorfismo retrógrado, já próximo ao campo de estabilidade de clorita:

$\mathrm{Tr}+\mathrm{Fo}=\mathrm{Di}+\mathrm{En}+\mathrm{H}_{2} \mathrm{O}$

Os serpentinitos de ambas as áreas ocupam, portanto, pontos distintos ao longo do caminho metamórfico, com as rochas do domínio da Faixa Ribeira representando produtos tardios de hidratação (retrometamorfismo) e as rochas do domínio da Faixa Brasília evoluindo para uma associação de mais alto grau com geração de olivina.

\section{Campo de estabilidade das associações minerais} Dois conjuntos quimicamente distintos são considerados: aquele formado por rochas cuja composição permite a formação de minerais cálcicos (sistema CMASH) e aquele formado por rochas onde cálcio é irrelevante (sistema MASH).

A figura 12 apresenta o campo de estabilidade atribuído às associações de minerais no sistema

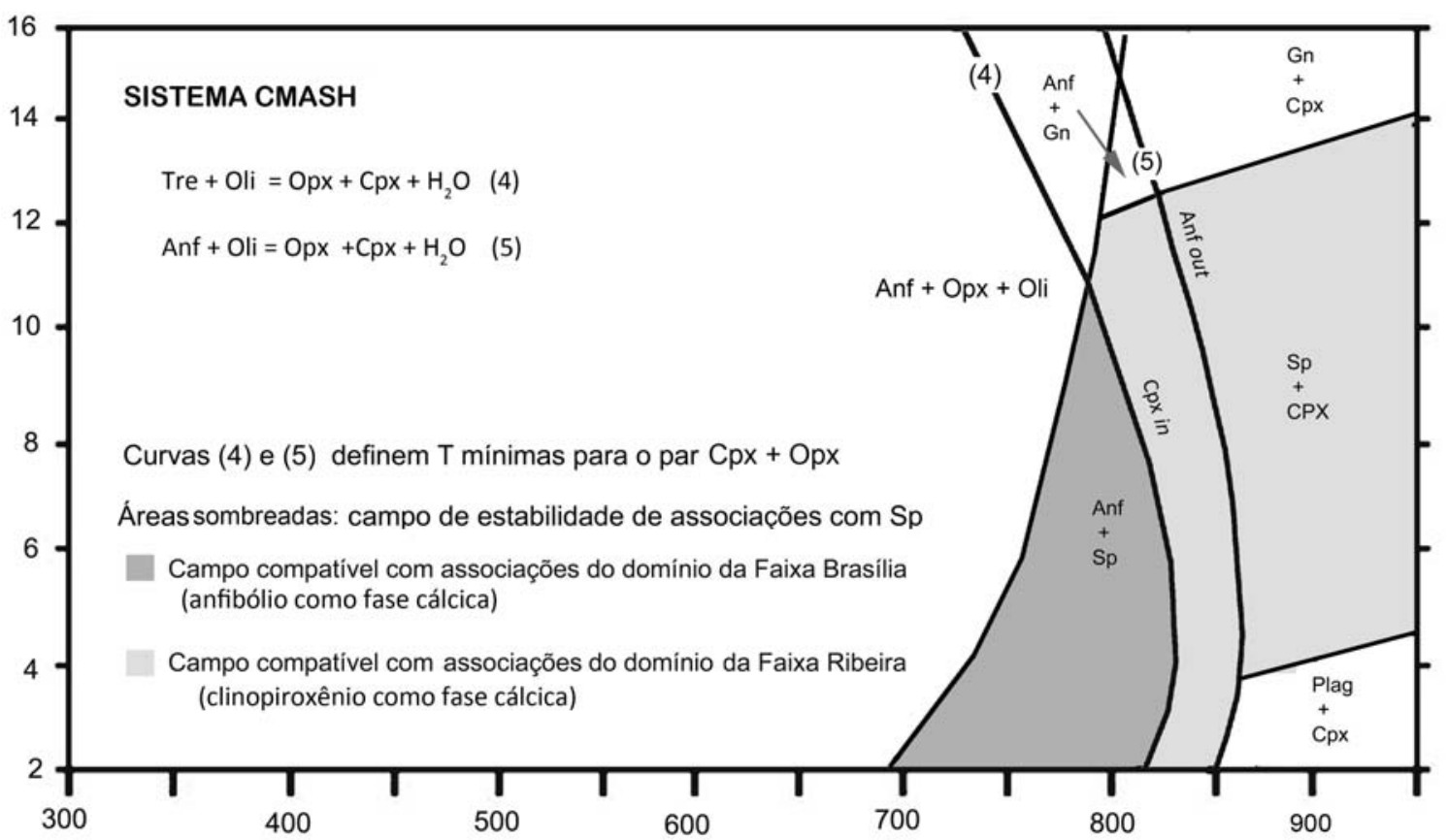

Figura 12 - Campos de estabilidade de associações minerais no sistema CMASH, segundo Bücher \& Frey (2002). Áreas sombreadas destacam campo de estabilidade de associações minerais encontradas em ambos os domínios. Números em parênteses indicam reações referenciadas no texto. 
CMASH para rochas ultramáficas de mais alto grau de ambos os domínios.

A formação de espinélio aluminoso por expulsão de alumínio da estrutura do ortopiroxênio denotada no meta-harzburgito pela textura simplectítica entre os minerais envolvidos na reação (7) indica, como visto anteriormente, alta temperatura de cristalização para o ortopiroxênio original e liberação gradual de alumínio ao longo do resfriamento. A figura 13 ilustra as temperaturas estimadas para a evolução desta rocha com base nos geotermômetros aplicados. As curvas 7a e 7b definem, respectivamente, a temperatura máxima e mínima obtida para a associação olivina+enstatita+espinélio ao longo desta reação contínua, enquanto a curva 8 ilustra as condições de formação de clorita por hidratação localizada da rocha.

A figura 14 apresenta o campo de estabilidade para antofilita, que aparece associada ao talco em metaortopiroxenito da Serra da Garça, no domínio tectônico da Faixa Ribeira. O campo à direita define condições metassomáticas com adição de $\mathrm{SiO}_{2}$. Em ambos os casos, a presença de antofilita na associação restringe as condições de pressão a um máximo de $10 \mathrm{kbar}$ no sistema MSH. Bucher \& Frey (2002) reportam a frequência de associações contendo antofilita em auréolas de contato e na fase de descompressão de rochas ultramáficas com forsterita+enstatita. Como observado na descrição petrográfica, a formação destes minerais está associada a uma fase retrógrada, com hidratação de enstatita e a possibilidade de reações metassomáticas envolvendo metamorfismo de contato deve ser, também, considerada em função da proximidade das lentes ultramáficas da Serra da Garça do maior corpo granítico da região (Fig. 2).

A tabela 7 apresenta um quadro das estimativas de pressão e temperatura para as associações de ambos os domínios e os critérios utilizados. Como pode ser observado, o domínio tectônico da Faixa Ribeira exibe uma grande variedade de rochas contendo piroxênio e olivina e que são representativas de um amplo intervalo de temperatura (entre 400 e $800^{\circ} \mathrm{C}$ ). No domínio tectônico da Faixa Brasília, não se observa tal variedade de litotipos e as temperaturas estimadas são inferiores (entre 500 e $640^{\circ} \mathrm{C}$ ), com incremento em direção a sul, na direção dos limites com o domínio Ribeira.

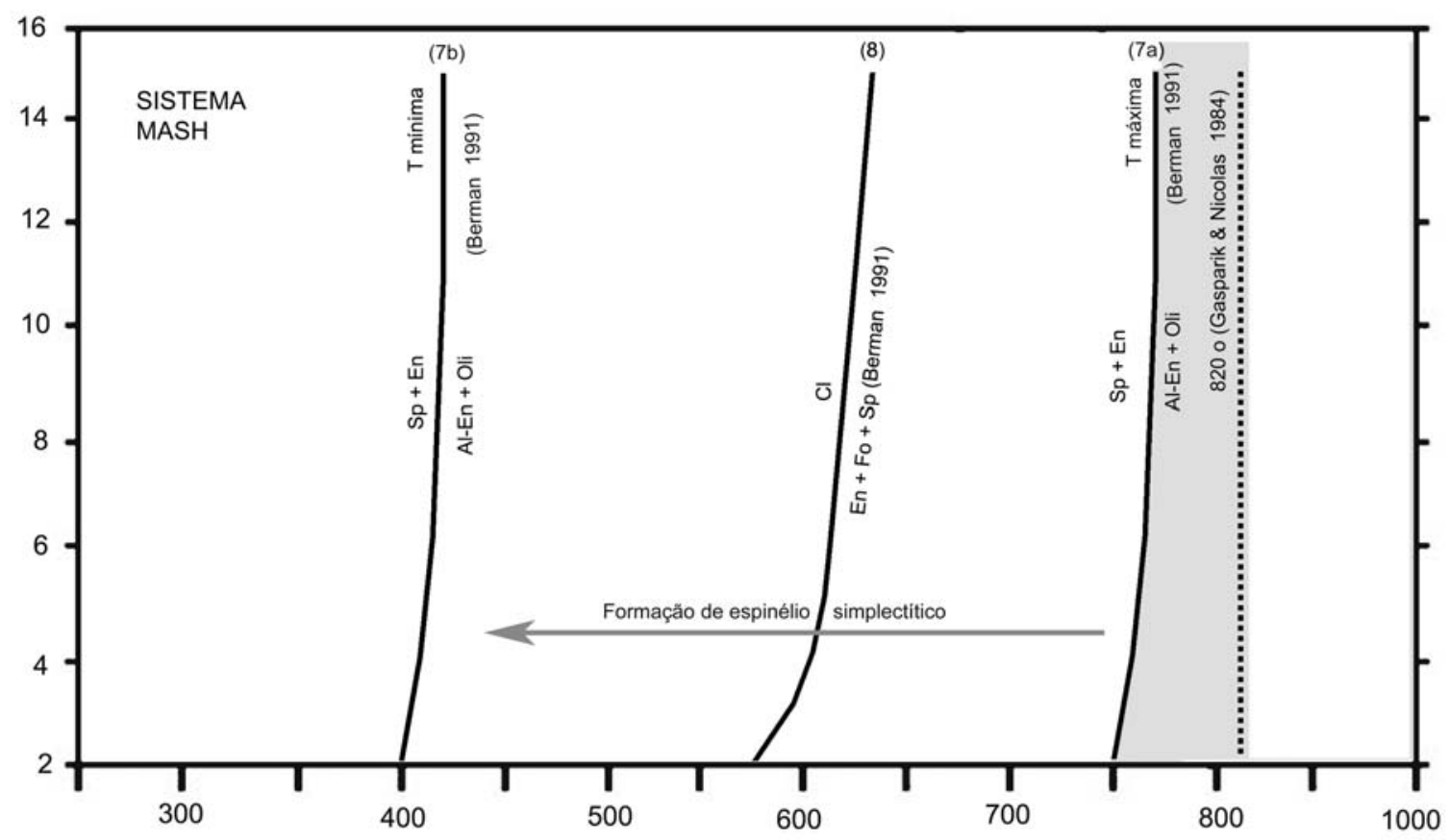

Figura 13 - Curvas de equilíbrio estimada para associações em metaespinélio harzburgito de Liberdade. Área sombreada: temperaturas máximas obtidas para a associação espinélio+ olivina+ortopiroxênio. Curvas (7a) e (7b): temperaturas máxima e mínima obtidas para a reação Al-En+xOl = xSp+(1+x)En. Curva (8): temperatura obtida para formação localizada de clorita por hidratação da associação. 


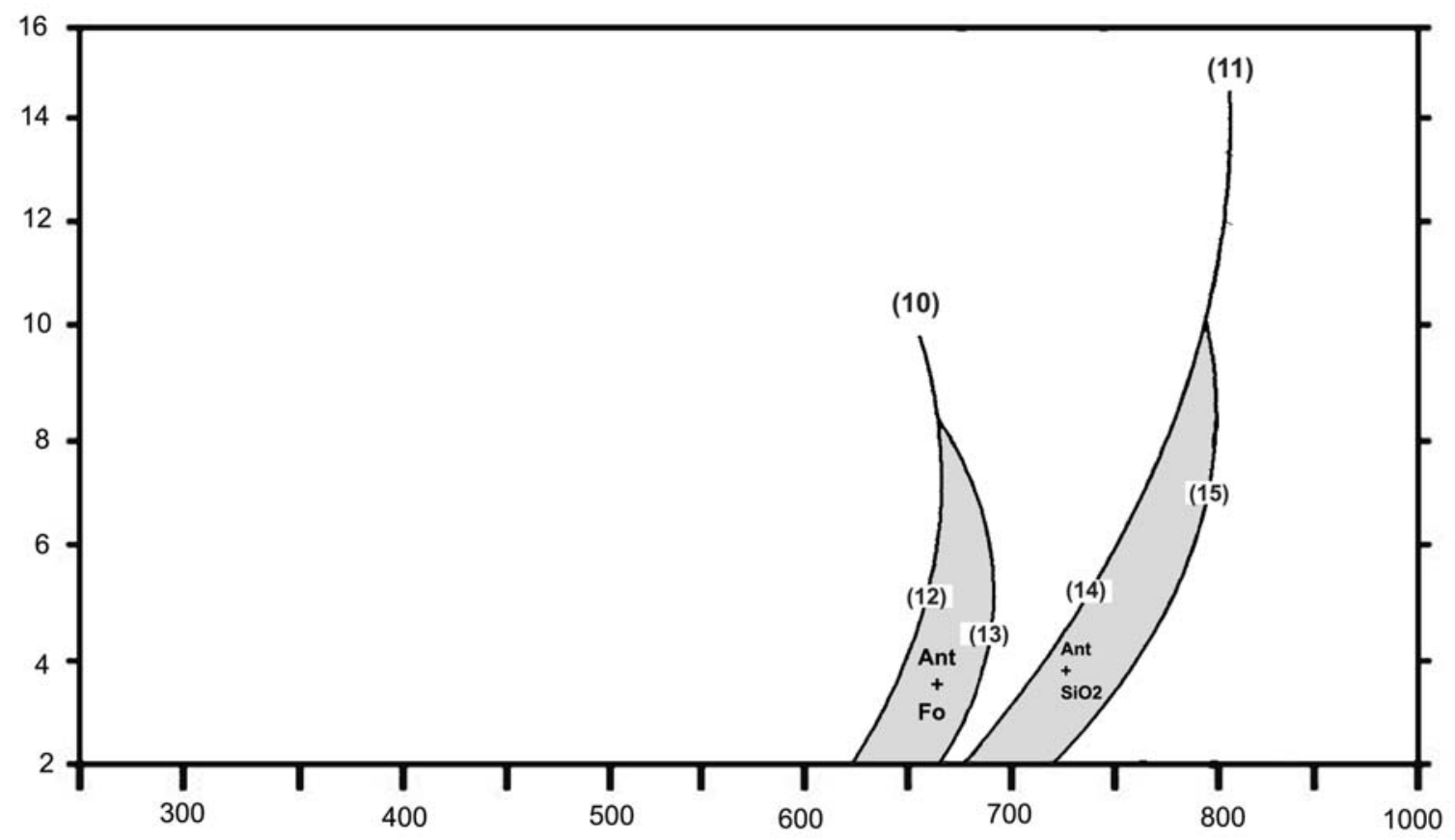

Figura 14 - Campos de estabilidade de antofilita (área sombreada). Números entre parêntese indicam reações referenciadas no texto.

Tabela 7 - Estimativas de pressão e temperatura para associações minerais de ambos os domínios tectônicos.

\begin{tabular}{|c|c|c|c|}
\hline Rocha & Critério & $\mathbf{T}\left({ }^{\circ} \mathrm{C}\right)$ & P (kbar) \\
\hline \multicolumn{4}{|c|}{ Domínio Tectônico da Faixa Ribeira } \\
\hline $\begin{array}{l}\text { Espinélio } \\
\text { meta-harzburgito } \\
\text { (Liberdade) }\end{array}$ & $\begin{array}{l}\text { - Campo de estabilidade da associação } \mathrm{sp}+\mathrm{en}+\mathrm{fo} \\
\text { - Equilíbrio (Berman 1991) da associação sp+fo+en com espinélio simplecttítico } \\
\text { - Equilíbrio (Berman 1991) da associação sp+fo+en com espinélio granoblástico } \\
\text { - \% Al2O3 em opx (Gasparik \& Newton 1984) - (opx associado a espinélio } \\
\text { simplectítico) } \\
\text {-\% Al2O3 em opx (Gasparik \& Newton 1984) - (opx associado a espinélio } \\
\text { granoblástico) } \\
\text { - Equilíbrio opx+ol+cl+sp (Berman 1991) }\end{array}$ & $\begin{array}{c}- \\
(400-550) \\
(550-750) \\
(560) \\
(820) \\
(600)\end{array}$ & $\begin{array}{c}8-20 \\
- \\
- \\
- \\
- \\
-\end{array}$ \\
\hline $\begin{array}{l}\text { Metawebsterítito } \\
\text { (Liberdade) }\end{array}$ & $\begin{array}{l}\text { - Campo de estabilidade da associação cpx }+ \text { opx }+ \text { ol+anf }+ \text { sp } \\
\text { - Par opx-cpx (Wells1977) } \\
\text { - Temperatura mínima de quebra do par Ca-anf + fo para formação de cpx }\end{array}$ & $\begin{array}{c}- \\
800 \\
>800\end{array}$ & $\begin{array}{c}5-14 \\
-\end{array}$ \\
\hline $\begin{array}{c}\text { Rochas a } \\
\text { antofilita } \\
\text { (Serra da Garça) } \\
\end{array}$ & - Condições propícias a coexistência de ant $+\mathrm{opx}+$ talco & $650-800$ & $\begin{array}{l}\text { Máxima } \\
\approx 10\end{array}$ \\
\hline $\begin{array}{l}\text { Olivina clorita/ } \\
\text { anfibólio fels } \\
\text { (Arantina) }\end{array}$ & - Condições de estabilidade da associação fo + anf + sp & $<800$ & $\begin{array}{l}\text { Máxima } \\
\quad=7\end{array}$ \\
\hline \multicolumn{4}{|c|}{ Domínio Tectônico da Faixa Brasília } \\
\hline $\begin{array}{l}\text { Espinélio-olivina } \\
\text { metaortopiroxenitos } \\
\text { (São Vicente de Minas } \\
\text { e Carrancas) }\end{array}$ & $\begin{array}{l}\text { - Equilíbrio oli-sp (Sack \& Ghiorso 1991) } \\
\text { - Campo de estabilidade opx+sp+oli+anf } \\
\text { - quilíbrio oli-opx-clorita-sp (Berman } 1991\end{array}$ & $\begin{array}{l}500-550 \\
- \\
580-640\end{array}$ & $\begin{array}{l}\text { Máxima } \\
=12\end{array}$ \\
\hline $\begin{array}{c}\text { Serpentinito } \\
\text { (Fazenda Rui Barbosa- } \\
\text { Carrancas) }\end{array}$ & • Formação de olivina metamórfica a partir de serpentina & $\begin{array}{l}\text { Mínima de } \\
\quad 400\end{array}$ & - \\
\hline
\end{tabular}


CONCLUSÕES Ao longo do cinturão ultramáfico exposto na região sul de Minas Gerais são encontradas rochas que representam diferentes estágios do metamorfismo regional. A despeito da natureza de seu protólito, é possível traçar um paralelo entre a evolução dos litotipos do domínio tectônico da Faixa Brasília e do domínio Ribeira.

No domínio tectônico da Faixa Brasília, a ausência de clinopiroxênio entre as rochas do sistema $\mathrm{CMASH}$ indica que temperaturas superiores a $800^{\circ} \mathrm{C}$ não foram atingidas, ficando a fase cálcica restrita a anfibólios. Nestas rochas, os geotermômetros aplicados indicam temperaturas máximas de $640^{\circ} \mathrm{C}$, com as rochas metapiroxeníticas de São Vicente de Minas apresentando temperaturas superiores, em torno de $50^{\circ} \mathrm{C}$, em relação aos piroxenitos de Carrancas, refletindo incremento de metamorfismo na direção sudeste. No domínio da Faixa Ribeira, metapiroxenitos do sistema CMASH exibem clinopiroxênio de origem metamórfica, indicando terem estas rochas alcançado condições de temperatura superiores aos seus equivalentes do domínio tectônico da Faixa Brasília. Nesta região as temperaturas máximas obtidas concentram-se entre 700 e $900^{\circ} \mathrm{C}$.

Não foi possível definir variações nas condições de pressão entre ambos os domínios. As associações e reações propostas são compatíveis com um intervalo de pressão entre 7 e 14 kbar que é propício às condições máximas de equilíbrio dos diversos litotipos, tanto nas rochas do domínio Ribeira, como no domínio tectônico da Faixa Brasília.

Diferenças de padrão também são observadas nas características da deformação das rochas metapiroxeníticas de ambas as regiões. Nos dois domínios, as rochas com associações de mais alto grau são caracterizadas pela formação de megacristais poiquiloblásticos de piroxênios. Porém, no domínio tectônico da Faixa Brasília predominam texturas granoblásticas, com deformação localizada, enquanto que as rochas do domínio Ribeira apresentam padrões complexos de deformação com texturas indicando que o metamorfismo progressivo foi acompanhado de deformação intensa.

Mesmo entre os tipos essencialmente hidratados notam-se características contrastantes entre as duas regiões. No caso dos serpentinitos há texturas claras que indicam a formação de serpentina pela hidratação de protólitos granulares entre rochas do domínio Ribeira, enquanto a textura entrelaçada e a forma alongada dos corpos de serpentinito do domínio tectônico da Faixa Brasília são sugestivas da hidratação de rochas com granulometria originalmente muito fina. Na região de Carrancas, há um exemplo de metamorfismo progressivo de serpentinito, dado pelo crescimento metamórfico de olivina, acompanhando a evolução progressiva dos metapiroxenitos locais.

No caso das rochas ricas em talco, observa-se que as condições de formação deste mineral podem ser bastante discrepantes. Associações contendo talco+antofilita na Faixa Ribeira são formadas sob condições de temperatura superiores àquelas produzidas por reações metassomáticas entre o corpo ultramáfico e as encaixantes ácidas, comuns entre as rochas do domínio tectônico da Faixa Brasília.

Deve-se acrescentar que a formação de talco, assim como clorita, resulta não apenas da ação de fluidos ao longo de zonas de cisalhamento que cortam estes corpos, mas também de trocas iônicas entre rochas ultramáficas e encaixantes ricas em quartzo, gerando os tipos não foliados. Embora a origem destas auréolas tenha sido discutida nos trabalhos de Almeida $(1992,1998)$, Pinheiro \& Suita (2008) atribuem à autora uma proposta de origem por metassomatismo de contato, do tipo termal, para estas auréolas. Trata-se de um erro de interpretação dos textos originais, pois a origem alóctone destes corpos ultramáficos está de acordo com as propostas de Almeida desde os seus primeiros trabalhos nestas regiões.

\section{Referências}

Almeida S. 1992. Petrografia e Geoquímica de Rochas Ultramáficas na Região de Liberdade e Carrancas, Minas Gerais. Dissertação de Mestrado, Instituto de Geociências, Universidade Federal do Rio de Janeiro, Rio de Janeiro, 166 p.

Almeida S. 1998. Petrologia de rochas ultramáficas associadas ao Grupo Andrelândia e seu embasamento, na região de Liberdade, Arantina, Andrelândia, São Vicente de Minas e Carrancas, MG. Tese de Doutorado. Instituto de Geociências, Universidade de São Paulo, São Paulo, 182 p.

Almeida S. 2002. A diversidade de texturas e associações minerais de rochas ultramáficas na região sul de Minas Gerais como resultado da atuação distinta de processos metamórficos e tectônicos ao longo da Faixa Ribeira. Rev. Ciên. Exatas e da Terra, 21(2):101-113.

Bebert C.O., Svisero D.P., Sial A.N., Meyer H.O.A. 1981. Upper mantle material in the Brazilian Shield. Earth Sci. Rev., 17:109-133

Berman R.G. 1991. Thermobarometry using multiequilibrium calculations: a new technique with petrologic applications. Can. Min., 75:328-344.

Bucher K. \& Frey M. 2002. Petrogenesis of Metamorphic Rocks. New York, Spring-Verlag, 318 p.

Campos Neto M.C. 2000. Orogenic Systems from Southwestern Gondwana: an approach to Brasiliano Pan African cycle and orogenic collage in southeastern 
Brazil. In: Cordani U.G., Milani E.J., Thomaz-Filho A., Campos D.A. (eds.) Tectonic Evolution of South America - 31 $1^{\text {st }}$ IGC. Rio de Janeiro, CPRM, p. 335-365.

Campos Neto M.C. \& Caby R. 1999. Neoproterozoic highpressure metamorfism and tectonic constraint from the nappe system south of the São Francisco Craton, southeast Brazil. Precambrian Research, 97:3-26.

Campos Neto M.C., Caby R. 2000. Terrane accretion and upward extrusion of high-pressure granulites in the Neoproterozoic nappes of southeast Brazil: Petrologic and structural constraints. Tectonics, 19:669-687.

Campos Neto M.C., Basei M.A.S., Vlach S.R.F., Caby R., Szabó G.A.J., Vasconcelos P. 2004. Migração de orógenos e superposição de orogêneses: Um esboço da colagem Brasiliana no sul do Cráton do São Francisco, SE - Brasil. Geologia USP. Série Científica, 4:13-40.

Campos Neto M.C., Janasi V.A., Basei M.A.S., Siga Jr. O. 2007. Sistema de nappes Andrelândia, setor oriental: litoestratigrafia e posição estratigráfica. Revista Brasileira de Geociências, 37(4-Suplemento):47-60.

Chernosky Jr. J.V., Day H.W., Caruso L.J. 1985. Equilibrium in the system $\mathrm{MgO}-\mathrm{SiO}_{2}-\mathrm{H}_{2} \mathrm{O}$ : experimental determinations of the stability of Mg-anthophillite. Am. Min., 70:223-236.

Deer W.A., Howie R.A., Zussman J. 1992. An Introduction to Rock forming mineral. $2^{\text {nd }}$ edition. Charlotte, Baker \& Taylor, $712 \mathrm{p}$.

Dick H.J.B. \& Bullen T. 1984. Chromian spinel as a petrogenetic indicator in abyssal and alpine-type peridotites and spatially associated lavas. Contr. Min. Petrol., 86:54-76.

Dick H.J.B. 1977. Partial melting in the Josefine peridotite I, the effects on mineral composition and its consequence for the geobarometry and geothermometry. Am. Jour. Sci., 277:8801-832.

Embury J.D. \& Nicholson R.B. 1965. The System Al-ZnMg. Acta Metall., 13:403.

Evans B.W. \& Frost. 1975. Chrome-spinel in progressive metamorphism - a preliminary analysis. Geoch. Cosm. Acta, 39:959-972.

Evans B.W. 1977. Metamorphism of Alpine peridotite and serpentinite. Ann. Rev. Earth Plan. Sci., 5:397-447.

Fujii T. 1977. Solubility of $\mathrm{Al}_{2} \mathrm{O}_{3}$ in enstatite coexisting with forsterite and spinel. Carneg. Iinst. Washington Yearb., 75:566-571.

Gasparik T. \& Newton R.C. 1984. The reversed alumina contents of orthopyroxene in equilibrium with spinel and forsterite in the system $\mathrm{MgO}-\mathrm{Al}_{2} \mathrm{O}_{3}-\mathrm{SiO}_{2}$. Contr. Min. Petrol., 85:186-196.

Green D.H. \& Ringwood A.E. 1970. Mineralogy of peridotitic composition under upper mantle conditions. Phys. Earth Planet. Sci. Inter., 3:359-371.

Greenwood H.J. 1963. The synthesis and stability of anthophillyte. Jour. Petrol., 4:317-351.

Greenwood H.J. 1971. Anthophillyte. Corrections and comments in its stability. Am. Jour. Sci., 270:151-154.

Haggerty S.E. 1991. Oxide mineralogy of the upper mantle. Rev. in Min., 24:355-416.

Hibbard M.J. 1995. Petrography to Petrogenesis. Englewood Cliffs, Prentice Hall Ed., 587 p.
Irvine T.N. 1967. Chromium spinel as a petrogenetic indicator, Part 2. Petrologic Aplications. Can. Jour. Earth Sci., 4:71-103.

Jenkins D.M. \& Chernosky Jr. J.V. 1986. Phase equilibria and crystallochemical properties of $\mathrm{Mg}$-chlorite. Am. Min., 71:924-936.

Jenkins D.M. 1983. Stability and compositions relations of calcic amphiboles in ultramafic rocks. Contrib. Min. Petrol., 83:375-384.

Johannes W. 1969. An experimental investigation of the system $\mathrm{MgO}-\mathrm{SiO}_{2}-\mathrm{H}_{2} \mathrm{O}-\mathrm{CO}_{2}$. Am. Jour. Sci., 272:423-437.

Leake B.E. 1978. Nomenclature of amphiboles. Can. Min., 16:501-520.

MacGregor I.D. 1974. The system $\mathrm{MgO}-\mathrm{Al}_{2} \mathrm{O}_{3}-\mathrm{SiO}_{2}$ : solubility of $\mathrm{Al}_{2} \mathrm{O}_{3}$ in enstatita for spinel and garnet peridotite compositions. Am. Min., 59:110-119.

Magalhães A.C. 1985. Geologia dos corpos ultramáficos da região entre São João del Rey e Liberdade, com ênfase especial na área de Carrancas. MG. Dissertação de Mestrado, Instituto de Geociências, Universidade Federal do Rio de Janeiro, Rio de Janeiro, 177 p.

Nilson A.A. 1984. O atual estágio do conhecimento dos complexos máficos-ultramáficos pré-cambrianos no Brasil: uma avaliação preliminar. In: SBG, Congresso Brasileiro de Geologia, 23, Anais, p. 4166-4203.

O’Hara M.J. 1967. Mineral facies in ultrabasic rocks. In: Wyllie P.J. Ultrabasic and Related Rocks. New Jersey, John Wiley \& Sons Inc., p. 7-18.

Obata M. \& Thompson A.B. 1981. Amphibole and chlorite in mafic and ultramafic rocks in the lower crust and upper mantle: a theoretical approach. Contrib. Min. Petrol., 77:74-81.

Obata M. 1976. The solubility of $\mathrm{Al}_{2} \mathrm{O}_{3}$ in orthopyroxenes in spinel and plagioclase peridotites and spinel pyroxenite. Am. Min., 61:804-816.

Obata M. 1980. The Ronda Peridotite: garnet-, spinel- and plagioclase-lherzolite facies and the P-T trajectories of a hight-temperature mantle intrusion. Jour. Petrol., 21(3):533-572.

Paciullo F.V.P., Ribeiro A., Andreis R.R., Trouw R.A.J. 2000. Andrelândia Basin, a neoproterozoic

intraplate continental margin, southern Brasília, Belt. Revista Brasileira de Geociências, 30:200-202.

Peternel R., Trouw R.A.J., Schmit R.S. 2005. Interferência entre duas faixas móveis Neoproterozóicas: o caso das Faixas Brasília e Ribeira no sudeste do Brasil. Revista Brasileira de Geociências, 35:97-310.

Pinheiro M.A.P. \& Suita M.T.F. 2008. Metamorfismo de fundo oceânico e alto grau em meta-peridotitos ofiolíticos neoproterozoicos, Faixa Brasília Sul, Minas Gerais. Revista Brasileira de Geociências, 38:686-699.

Poldervaart A. \& Hess H.H. 1951. Pyroxenes in the crystallization of basaltic magma. Jour. Geol., 59:472-489.

Ribeiro A., Paciullo F.V.P, Andreis R.R., Trouw R.A.J., Heilbron M. 1990. Evolução policíclica proterozóica no sul do Craton do São Francisco: análise da região de São João del Rei e Andrelândia, MG. In: SBG, Congresso Brasileiro de Geologia, 36, Anais, p. 2605-2614.

Ribeiro A., Trouw R.A.J., Andreis R., Paciullo F.V.P., Valença J.G. 1995. Evolução das bacias proterozóicas e 
termo-tectonismo brasiliano na margem sul do craton do São Francisco. Rev. Bras. Geoc., 25(4):235-248.

Sack R.O. \& Ghiorso M.S. 1991. Chromian spinel as petrogenetic indicator: thermodynamics and petrological applications. Am. Min., 76:827-847.

Schmâdicke E. \& Evans B.W. 1997. Garnet-bearing rocks from the Erzgebirge, and their relation to other settings in the Bohemian Massif. Contrib. Min. Petrol., 127:57-74.

Smith D. \& Riter A.J.C. 1997. Genesis an evolution of low-Al orthopyroxene in spinel peridotites xenoliths, Grand Cayon fiel, Arizona, USA. Contrib. Min. Petrol., 127:391-404.

Tröger W.E. 1979. Optical Determination of Rock-Forming Minerals (Part 1 - Determination Tables). Stuttgart, Schweizerbartsche Verlagsbuchhandlung, $188 \mathrm{p}$.

Trouw R.A.J., Ribeiro A., Paciullo F.V.P. 1986. Contribuição à geologia da folha Barbacena 1:250.000. In: SBG, Congresso Brasileiro de Geologia, 33, Anais, p. 974-986.
Trouw R.A.J., Paciulo F.V.P., Ribeiro A. 1994. AFaixa Alto Rio Grande reinterpretada como zona de interferência entre a Faixa Brasília e a Faixa Ribeira. In: SBG, Congresso Brasileiro de Geologia, 38, Resumos, p. 234-235.

Trouw R.A.J., Heilbron M., Ribeiro A., Valeriano C.M., Almeida J.C.H., Tupinambá M., Andreis R.R. 2000. The central segment of the Ribeira Belt. In: Cordani U.G., Milani E.J., Thomaz Filho A., Campos D.A. (eds.) Tectonic Evolution of South America - 31 $1^{\text {st }}$ IGC. Rio de Janeiro, CPRM, p. 287-310.

Vance J.A. \& Dungan M.A. 1977. Formation of peridotites by deserpentinization in the Darrington and Sultan areas, Cascade Mountais, Washington. Bull. Geol. Soc. Am., 88:1497-1508.

Wells P. 1977. Pyroxene thermometry in simple and complex system. Contrib. Min. Petrol., 62:129-139.

Manuscrito ID 20761

Submetido em 13 de fevereiro de 2011 Aceito em 07 de fevereiro de 2012 